\title{
Identification of super-infected Aedes triseriatus mosquitoes collected as eggs from the field and partial characterization of the infecting La Crosse viruses
}

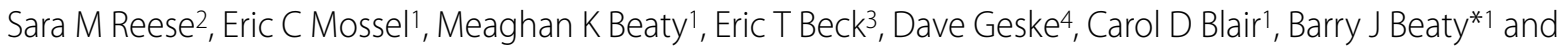 \\ William C Black'
}

\begin{abstract}
Background: La Crosse virus (LACV) is a pathogenic arbovirus that is transovarially transmitted by Aedes triseriatus mosquitoes and overwinters in diapausing eggs. However, previous models predicted transovarial transmission (TOT) to be insufficient to maintain LACV in nature.

Results: To investigate this issue, we reared mosquitoes from field-collected eggs and assayed adults individually for LACV antigen, viral RNA by RT-PCR, and infectious virus. The mosquitoes had three distinct infection phenotypes: 1) super infected (SI+) mosquitoes contained infectious virus, large accumulations of viral antigen and RNA and comprised 17 of 17,825 (0.09\%) of assayed mosquitoes, 2) infected mosquitoes (I+) contained no detectable infectious virus, lesser amounts of viral antigen and RNA, and comprised 3.7\% of mosquitoes, and 3) non-infected mosquitoes (I-) contained no detectable viral antigen, RNA, or infectious virus and comprised $96.21 \%$ of mosquitoes. SI+ mosquitoes were recovered in consecutive years at one field site, suggesting that lineages of TOT stably-infected and geographically isolated Ae. triseriatus exist in nature. Analyses of LACV genomes showed that $\mathrm{SI}+$ isolates are not monophyletic nor phylogenetically distinct and that synonymous substitution rates exceed replacement rates in all genes and isolates. Analysis of singleton versus shared mutations (Fu and Li's F*) revealed that the SI+ LACV M segment, with a large and significant excess of intermediate-frequency alleles, evolves through disruptive selection that maintains SI+ alleles at higher frequencies than the average mutation rate. A QTN in the LACV NSm gene was detected in $\mathrm{SI}+$ mosquitoes, but not in I+ mosquitoes. Four amino acid changes were detected in the LACV NSm gene from SI+ but not I+ mosquitoes from one site, and may condition vector super infection. In contrast to NSm, the NSs sequences of LACV from SI+ and I+ mosquitoes were identical.
\end{abstract}

Conclusions: $\mathrm{SI}+$ mosquitoes may represent stabilized infections of Ae. triseriatus mosquitoes, which could maintain LACV in nature. A gene-for-gene interaction involving the viral NSm gene and a vector innate immune response gene may condition stabilized infection.

\section{Background}

La Crosse virus (LACV) (Family: Bunyaviridae, Genus: Orthobunyavirus, Serogroup: California) is the leading cause of arboviral neuroinvasive disease in children in the United States [1,2]. LACV encephalitis occurs primarily

* Correspondence: bbeaty@colostate.edu

${ }^{1}$ Arthropod-Borne and Infectious Diseases Laboratory, Department of Microbiology, Immunology and Pathology, Colorado State University, Fort Collins, Colorado 80523-1692, USA

Full list of author information is available at the end of the article in the upper Midwestern and the Eastern United States, reflecting the distribution of the mosquito vector, Aedes triseriatus (Say), and its preferred vertebrate hosts, chipmunks and tree squirrels. LACV is transovarially transmitted by Ae. triseriatus and overwinters in the diapausing eggs [3-5].

In the laboratory, the transovarial transmission (TOT) rate (percentage of infected females that transmit virus to their progeny) and filial infection rate (FIR, percentage of 
infected progeny from a female) can each exceed 70\% [6]. However, LACV infection rates in Ae. triseriatus collected as eggs or larvae from the field are much lower. For example, LACV was isolated from only 10 of 1,698 (infection rate $=0.006)$ mosquitoes that were collected as larvae from overwintered eggs [5]. In another study, the minimum field infection rates for LACV in larvae from overwintered eggs ranged from 0.003 - 0.006 [7]. The dramatic difference in LACV infection rates between field and laboratory studies could result from deleterious effects of virus infection on embryos during stressful periods, such as overwintering [8], or from virus clearance by the innate immune response of the vector [9-12].

Mathematical models developed to investigate parameters that condition transmission and persistence in nature of LACV [13] and Keystone virus (KEYV) (Family: Bunyaviridae, Genus: Orthobunyavirus, Serogroup: California) $[14,15]$ suggested that the observed field infection rates for LACV are insufficient to maintain the virus in nature. For KEYV, the model suggests that the TOT rate must be at least 0.1 and there must be vertebrate-mediated amplification in order for KEYV to be maintained in nature. Infection rates detected in field collected larvae are significantly less than $0.1[4,5,7]$. Even when using infection rates obtained in the laboratory, the models suggest that LACV could not persist by TOT alone for more than a few generations $[6,13]$. Horizontal transmission would be necessary to complement TOT to maintain a "stable" LACV prevalence from year to year in the vector population. However, herd immunity in chipmunks and tree squirrels in forested areas can exceed 90\%; thus most mosquito feedings would be on dead end hosts, interrupting horizontal amplification of the virus [13-15]. Alternate mechanisms must condition LACV persistence in its endemic foci.

LACV could be maintained in nature by stabilized infection of Ae. triseriatus. Stabilized infection was first observed with Sigma virus (SIGMAV, Family: Rhabdoviridae) and Drosophila melanogaster fruit flies [16]. Infection of female D. melanogaster with SIGMAV by inoculation resulted in a "nonstabilized" infection with a small proportion of the developing oocytes and the resultant progeny becoming transovarially infected [17]. However, if germarium infection occurred, the progeny were stably-infected, and SIGMAV was transmitted to nearly $100 \%$ of progeny. A relatively small number of stablyinfected females could maintain virus prevalence at a constant level, assuming that any detrimental effects of the infection (e.g., longevity, fecundity, and development) are balanced by horizontal transmission $[18,19]$. Stabilized infection with California encephalitis virus (CEV) (Family: Bunyaviridae, Genus: Orthobunyavirus, Serogroup: California) has been demonstrated in Ae. dorsalis
[19]. Stably-infected females transmitted the virus to more than $90 \%$ of progeny through five laboratory generations. Analysis of field collected Ae. triseriatus mosquitoes suggested the possibility of stabilized LACV infection [20]. Some Ae. triseriatus mosquitoes collected as eggs from the field and processed individually contained large amounts of LACV antigen and LACV RNA [20]. We designated these as super-infected (SI+) mosquitoes, and our current working hypothesis is that these $\mathrm{SI}+$ mosquitoes represent stably-infected lineages of $A e$. triseriatus.

To establish a stabilized infection in Ae. triseriatus, LACV must avoid or perturb the vector innate immune response. RNAi and apoptosis are potent anti-arboviral innate immune responses in mosquitoes [9-12,21,22]. Recent studies revealed the fundamental role of autophagy in D. melanogaster response to vesicular stomatitis virus infection [23,24]. Importantly, ovarian follicle degeneration in D. melanogaster is conditioned by both apoptosis and autophagy, which share some common signaling pathway caspase components $[25,26]$. Because of the critical role of TOT, it would be especially important for LACV to avoid induction of an autophagic response in infected follicles [27]. Some viruses that infect arthropods have evolved viral inhibitors of RNAi [28]. Tomato spotted wilt virus (Family: Bunyaviridae, Genus:Tospovirus), NSs protein suppresses RNA silencing in infected plants [29]. Arboviruses in the family Bunyaviridae can modulate the vertebrate host innate immune response. For example, the LACV NSs protein can counteract the RNAi response [30] and the Rift Valley fever virus (Family: Bunyaviridae, Genus: Phlebovirus) NSm protein can suppress apoptosis [31] in vertebrate cells. However, little is known about the role of these genes in perturbing vector innate immune responses. LACV induces an RNAi response in both Aedes albopictus and Ae. triseriatus mosquito cell cultures that is not suppressed by the NSs protein [32], but nothing is known about this response in vivo in tissues and organs of Ae.triseriatus.

The goals of this study were to investigate the prevalence of SI+ mosquitoes in sites in the LACV endemic region, to determine the genetic relatedness of the SI+ virus isolates, and to characterize LACV genes potentially associated with perturbation of apoptotic/ autophagic and RNAi responses in SI+ mosquitoes.

\section{Results}

Detection of three LACV infection phenotypes in Ae. triseriatus mosquitoes from field collected eggs

Mosquitoes were collected as eggs from field sites in Wisconsin, Minnesota, and Iowa (Figure 1), hatched and reared to adults, and then assayed by immunofluorescence assay (IFA), virus isolation, and reverse transcrip- 
tion-PCR (RT-PCR). Based upon the results, mosquitoes were assigned to three infection phenotypes: $\mathrm{SI}+$ mosquitoes contained infectious virus and major accumulations of viral antigen and nucleic acid, I+ mosquitoes contained detectable amounts of viral antigen and nucleic acid but no detectable virus in cell culture assays, and I- mosquitoes that contained no detectable viral antigen or nucleic acid or virus.

IFA

The three infection phenotypes were detected in field collections (Figure 2); the distribution and prevalence rates of the $\mathrm{SI}+$ and I+ mosquitoes in collections made from the LACV endemic area in 2006 and 2007 are provided in Table 1. In total, 17,825 mosquitoes collected in 2006 and 2007 were assayed by IFA. Overall, 17 of 17,825 mosquitoes (prevalence rate: 0.0009 ) had the SI+ phenotype, 664 of 17,825 mosquitoes (prevalence rate: 0.037 ) were I+, and 17,161 of 17,825 mosquitoes were I- (Table 1). In 2006, 2 of 6,761 mosquitoes (prevalence rate $=$ 0.0003 ) were SI+ compared to 15 of 11,064 mosquitoes (prevalence rate $=0.0014$ ) in 2007.

\section{Virus isolation and titer}

IFA positive mosquitoes were assayed for infectious virus in cell culture. LACV was isolated only from the SI+ mosquitoes (data not shown). The LACV titer of the abdomen of 11 SI+ mosquitoes from the 4 different collecting sites ranged from $2.7-4.7 \log _{10} \mathrm{TCID}_{50} / \mathrm{ml}$ (average $=3.2$ $\left.\log _{10} \mathrm{TCID}_{50} / \mathrm{ml}\right)$. This did not differ significantly from the mean titer observed in the TOT-permissive laboratory colonized mosquitoes $\left(3.9 \log _{10} \mathrm{TCID}_{50} / \mathrm{ml}\right)(\mathrm{p}>$ 0.05) [20].

In contrast to the SI+ mosquitoes, LACV was not isolated in Vero E6 or BHK-21 cells from any of 213 I+ mosquitoes assayed. To potentially increase virus isolation sensitivity, supernatant fluid homogenates of 22 I+ mosquitoes were blind passaged [33] in BHK-21 and Vero E6 cell monolayers and some were assayed by intrathoracic inoculation of Ae. triseriatus mosquitoes, but again no isolates were obtained (data not shown).

\section{RT-PCR}

IFA positive mosquitoes were also processed by RT-PCR to amplify viral RNA sequences for phylogenetic, gene

Table 1: Prevalence and distribution of LACV SI+ and I+ mosquitoes in the 2006 and 2007 collections

\begin{tabular}{|c|c|c|c|c|c|c|c|c|c|c|c|c|}
\hline \multirow[b]{3}{*}{$\begin{array}{l}\text { County, } \\
\text { State }\end{array}$} & \multicolumn{6}{|c|}{ I+ } & \multicolumn{6}{|c|}{ S+ } \\
\hline & \multicolumn{3}{|c|}{2006} & \multicolumn{3}{|c|}{2007} & \multicolumn{3}{|c|}{2006} & \multicolumn{3}{|c|}{2007} \\
\hline & PosMos & $\begin{array}{l}\text { Total } \\
\text { Tested }\end{array}$ & Prev & PosMos & $\begin{array}{l}\text { Total } \\
\text { Tested }\end{array}$ & Prev & Pos Mos & $\begin{array}{l}\text { Total } \\
\text { Tested }\end{array}$ & Prev & PosMos & $\begin{array}{l}\text { Total } \\
\text { Tested }\end{array}$ & Prev \\
\hline Clayton, IA & $\mathrm{N} / \mathrm{A}$ & $\mathrm{N} / \mathrm{A}$ & N/A & 3 & 198 & 0.015 & $\mathrm{~N} / \mathrm{A}$ & N/A & $\mathrm{N} / \mathrm{A}$ & 0 & 198 & 0 \\
\hline $\begin{array}{l}\text { Crawford, } \\
\text { WI }\end{array}$ & 12 & 555 & 0.022 & 68 & 1561 & 0.044 & 1 & 555 & 0.0018 & 4 & 1561 & 0.0026 \\
\hline lowa, WI & 22 & 792 & 0.028 & 4 & 188 & 0.021 & 0 & 792 & 0 & 0 & 188 & 0 \\
\hline $\begin{array}{l}\text { LaCrosse, } \\
\text { WI }\end{array}$ & 12 & 605 & 0.02 & 129 & 3097 & 0.042 & 0 & 605 & 0 & 0 & 3097 & 0 \\
\hline $\begin{array}{l}\text { Lafayette, } \\
\text { WI }\end{array}$ & 35 & 902 & 0.039 & 19 & 275 & 0.069 & 0 & 902 & 0 & 4 & 275 & 0.0145 \\
\hline $\begin{array}{l}\text { Monroe, } \\
\text { WI }\end{array}$ & 1 & 183 & 0.006 & 42 & 1005 & 0.042 & 0 & 183 & 0 & 0 & 1005 & 0 \\
\hline Vernon, WI & 37 & 1122 & 0.033 & 45 & 1770 & 0.025 & 1 & 1122 & 0.0009 & 0 & 1770 & 0 \\
\hline $\begin{array}{l}\text { Houston, } \\
\text { MN }\end{array}$ & 89 & 1744 & 0.051 & 51 & 1318 & 0.039 & 0 & 1744 & 0 & 7 & 1318 & 0.0053 \\
\hline $\begin{array}{l}\text { Winona, } \\
\text { MN }\end{array}$ & 24 & 858 & 0.028 & 74 & 1652 & 0.045 & 0 & 858 & 0 & 0 & 1652 & 0 \\
\hline Total & 232 & 6761 & & 432 & 11064 & & 2 & 6761 & & 15 & 11064 & \\
\hline $\begin{array}{l}\text { Overall } \\
\text { Prevalence } \\
* *\end{array}$ & & & 0.034 & & & 0.039 & & & 0.0003 & & & 0.0014 \\
\hline
\end{tabular}




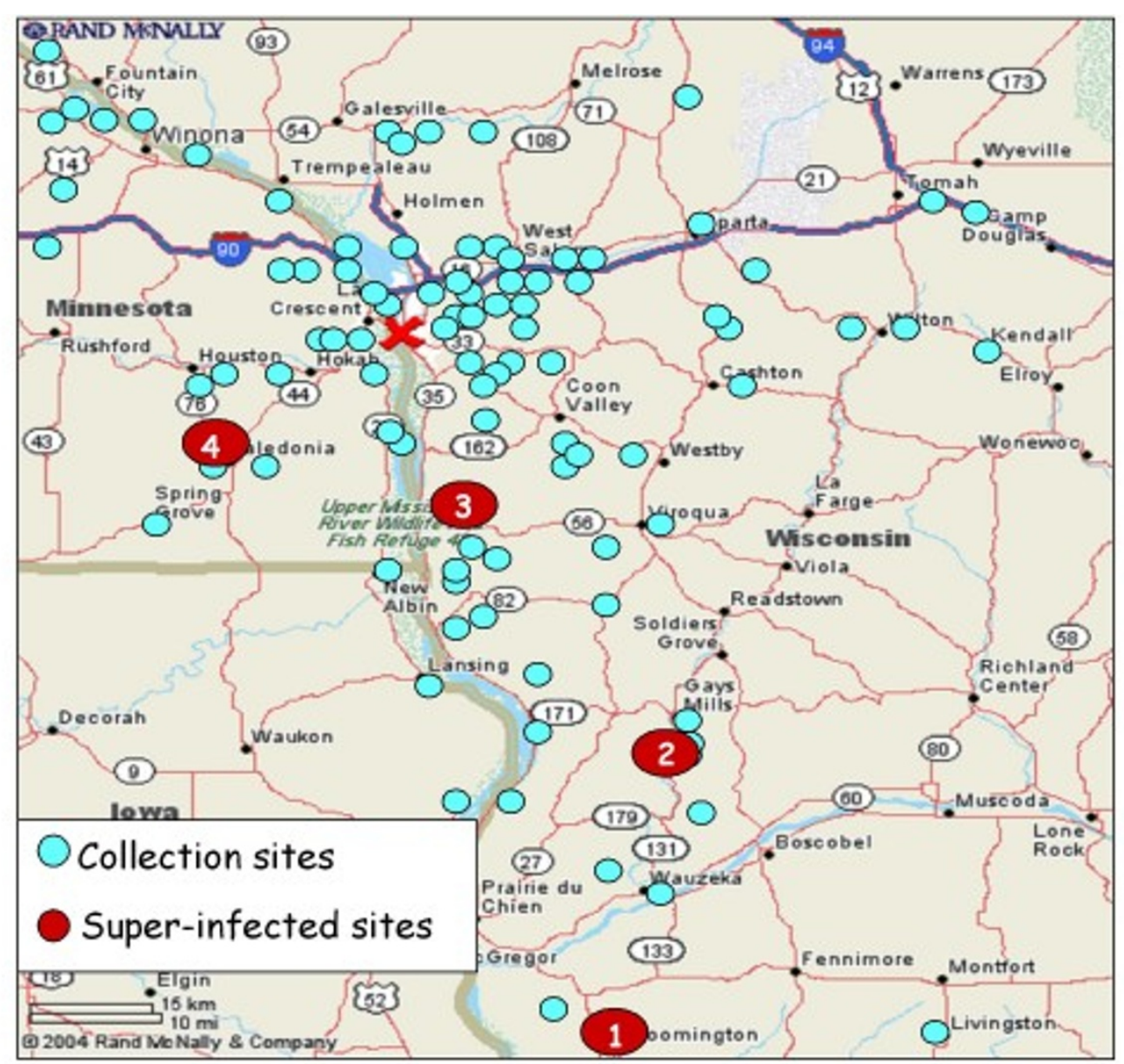

Figure 1 Aedes triseriatus mosquito collection sites in Minnesota, Wisconsin, and lowa. Circles represent the collection sites. Red circles are the sites where LACV super-infected mosquitoes were collected in 2006 and 2007. Site 1 - BEN2 Lafayette County, WI, Site 2 - NAT, Crawford County, WI. Site 3 - SVP Vernon County, WI, and Site 4 - CAL-GA Houston County, MN. La Crosse, WI is identified with the X.

structure, and molecular evolution analyses. RNA was readily amplified from all SI+ mosquitoes. Viral RNA was also amplified from I+ mosquitoes, but the RT-PCR assay and protocols needed further optimization, presumably because of reduced amounts of viral RNA in some mosquitoes [34]. For later analyses, we developed a nested RT-PCR system to more easily amplify sequences from I+ mosquitoes.

\section{Distribution of LACV SI+ and I+ mosquitoes in geographic field collections of Ae. triseriatus}

The prevalence of LACV-infected mosquitoes was determined in field collections from 2006 and 2007 (Table 1). In 2006, SI+ mosquitoes were collected from Vernon County (SVP/Vernon, WI/Mosquito/2006 Site 3 (Figure 1)) and Crawford County (NAT/Crawford, WI/Mosquito/2006 Site 2 (Figure 1)). In 2007, SI+ mosquitoes were collected from Crawford County (NAT/Crawford, WI/Mosquito/2007), Lafayette County (BEN2/Lafayette, WI/Mosquito/2007 Site 1 (Figure 1)) and Houston
County (CAL-GA/Houston, MN/Mosquito/2007/Site 4 (Figure 1)) (Table 1). Prevalence rates of SI+ mosquitoes differed between sites and years, ranging from 0.0009 at one site in Vernon County, WI in 2006 to 0.015 at a site in Lafayette County, WI in 2007. Notably the prevalence rate for SI+ mosquitoes at one site in Crawford County, WI was 0.018 in 2006 and 0.026 in 2007. This was the only site to yield SI+ mosquitoes in both years of the study.

\section{Prevalence of $\mathrm{SI}+$ mosquitoes in selected "hot spots"}

To further investigate the prevalence of SI+ mosquitoes, eggs from multiple liners were hatched from "hot spots" where $>1 \mathrm{SI}+$ mosquito had been detected previously. The SI+ and I+ prevalence rates were determined (Table 2). SI+ prevalence rates ranged from 0.012 to 0.121 in hot spots. At the SVP/Vernon, WI/2006 site, 1 of 84 (prevalence rate $=0.012)$ was SI+ (Table 2). At the BEN2/Layfayette, WI/2007 site, 4 of $220(0.018)$ were SI+. At the CAL-GA/Houston, MN/2007 site, 7 of 58 mosquitoes 


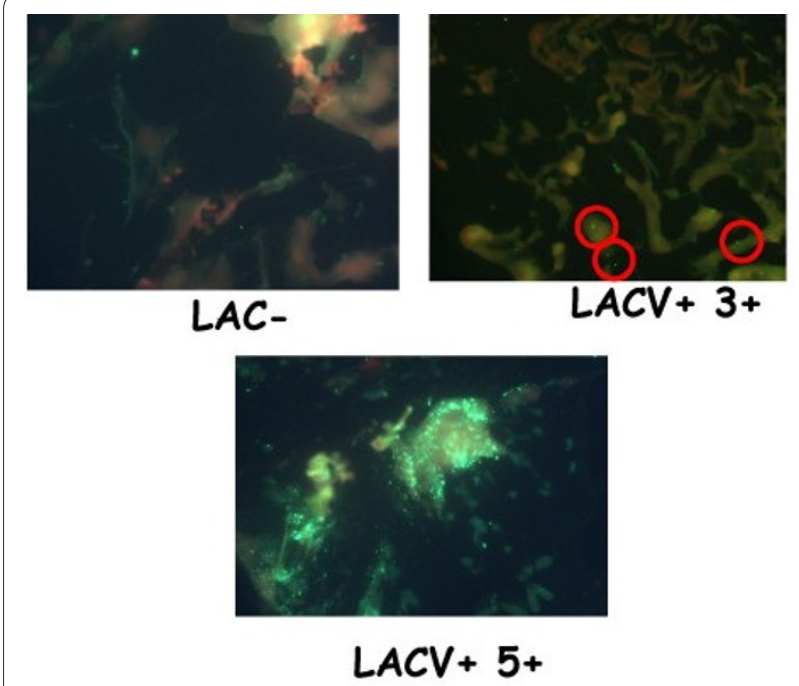

Figure 2 La Crosse virus antigen in infected, field-collected Aedes triseriatus mosquitoes. Mosquitoes were collected as eggs from the sites. Eggs were induced to hatch in the laboratory and emerged adults were assayed directly for the presence of LACV antigen by IFA (see Methods and Materials).

(0.12) were SI+ (Table 2). Field collected mosquitoes from the respective sites were tested throughout the summer and interestingly, SI+ mosquitoes were only identified at each collection site once a year (Table 2).

I+ mosquitoes were also more prevalent in hot spots. The I+ prevalence rate for each site was compared to the overall prevalence rate of 0.038 using a Fisher's exact test to determine whether they differed significantly (Table 2). The prevalence of I+ mosquitoes in NAT/Crawford, WI/ 2007 and CAL-GA/Houston, MN/2007 differed significantly $(\mathrm{p}=0.01)$ from the overall prevalence rate of I+ mosquitoes. The I+ prevalence rates observed in SVP/ Vernon, WI/2006 and BEN2/Layfayette, WI/2007 were significantly greater $(\mathrm{p}=0.05)$ than the overall $\mathrm{I}+$ prevalence rate.

Phylogenetic analysis of virus isolates from $\mathrm{SI}+$ mosquitoes The three genome segments of plaque purified viruses from selected SI+ mosquitoes were sequenced and deposited in GenBank (Table 3). The sequences were analyzed phylogenetically alongside previously published LACV sequences (Table 3) using a maximum likelihood (ML) analysis to test whether SI+ isolates represent 1) a monophyletic group that is 2) phylogenetically distinct previously published LACV sequences. One virus isolate was analyzed from each of the four SI+ collection sites (Figure 1). ML trees were created for the entire S, M and L segments (Figures 3, 4, and 5, respectively) and for the NSm gene (Figure 6).

The $\mathrm{S}$ segment ML tree (Figure 3 ) contained 3 well supported clades. One clade contained virus isolates from Wisconsin and Minnesota with $89 \%$ support. Internal to this, a clade with $87 \%$ support contained the MN Human 1960 and the WI Mosquito 1977 isolates. The third clade with $100 \%$ support contained the NAT/Crawford, WI/ 2006 and 2007 SI+ isolates. Note the long branch associated with NAT/Crawford clade demonstrating that these SI+ isolates are genetically distinct. However, also note that these two isolates collected from the same site in consecutive years are very similar to one another. The other three SI+ isolates are paraphyletic and therefore not phylogenetically distinct from the previously published LACV isolates. The S segment therefore suggests that SI+ isolates are not a monophyletic group. The trees in Figure 3 are not rooted and therefore do not suggest that SI+ lineages are basal.

The M segment ML tree (Figure 4) contains many well supported clades. As with the S segment, $\mathrm{M}$ segments in SI+ isolates do not form a monophyletic group and instead arise four times independently on clades that share a common ancestor with the previously published LACV isolates. Further, unlike the $S$ phylogeny, in no case are $\mathrm{SI}+$ isolate branch lengths long, suggesting sequence similarity to the previously published isolates. Note again that the NAT/Crawford isolates are very similar to one another.

The $\mathrm{L}$ segment ML tree contained the same patterns found in the M segment ML tree (Figure 5). One interesting additional observation is the phylogenetic placement of the isolate Wisconsin/Mosquito/1977. In the S seg-

Table 2: Prevalence of SI+ and I+ mosquitoes at "hot spots" in 2006 and 2007

\begin{tabular}{|c|c|c|c|c|c|}
\hline Site/Year & County & Date & \#Mosquitoes & I+ (Prevalence) & SI+ (Prevalence) \\
\hline SVP/2006 & Vernon, WI & $8 / 31 / 2006$ & 84 & $7(0.083)^{*}$ & $1(0.012)$ \\
\hline NAT/2006 & Crawford, WI & 2006 & 67 & $5(0.074)$ & $1(0.015)$ \\
\hline NAT/2007 & Crawford, WI & $7 / 17 / 2007$ & 475 & $30(0.063)^{* *}$ & $4(0.008)$ \\
\hline BEN 2/2007 & Lafayette, WI & $9 / 10 / 2007$ & 220 & $15(0.068)^{*}$ & $4(0.018)$ \\
\hline CAL-GA/2007 & Houston, WI & $8 / 27 / 2007$ & 58 & $7(0.121)^{* *}$ & $7(0.121)$ \\
\hline Total & & & 904 & $64(0.071)$ & $17(0.019)$ \\
\hline
\end{tabular}


Table 3: Virus RNA sequences used in phylogenetic and molecular evolutionary analyses of virus isolates.

\begin{tabular}{|c|c|c|c|c|c|}
\hline Virus Isolatea & Pheno-type & Passage History & Segment/Gene & $\begin{array}{c}\text { Accession } \\
\text { Number }\end{array}$ & Ref \\
\hline \multirow[t]{3}{*}{$\begin{array}{l}\text { Minnesota/ } \\
\text { Human/1960 }\end{array}$} & & $\mathrm{C} 6 / 362$ & S & $\mathrm{EF} 485030$ & [32] \\
\hline & & & M & EF485031 & \\
\hline & & & L & EF485032 & \\
\hline $\begin{array}{l}\text { Alabama/ } \\
\text { Mosquito/1963 }\end{array}$ & & Suckling mice 3 & M & DQ426682 & [33] \\
\hline $\begin{array}{l}\text { Ohio/Mosquito/ } \\
1965\end{array}$ & & $\begin{array}{c}\text { Suckling mice } 4 \text {, } \\
\text { Vero } 1\end{array}$ & M & DQ426683 & [33] \\
\hline $\begin{array}{l}\text { New York/ } \\
\text { Mosquito/1974 }\end{array}$ & & $\begin{array}{l}\text { Suckling mice 4, } \\
\text { BHK } 4\end{array}$ & M & $\underline{\mathrm{D} 10370}$ & [34] \\
\hline \multirow[t]{3}{*}{$\begin{array}{l}\text { Wisconsin/ } \\
\text { Mosquito/1977 }\end{array}$} & & Unknown & S & DQ1961120 & [32] \\
\hline & & & M & DQ196119 & \\
\hline & & & L & $\underline{\mathrm{DQ} 196118}$ & \\
\hline \multirow[t]{3}{*}{$\begin{array}{l}\text { Wisconsin/ } \\
\text { Human/1978-A }\end{array}$} & & $\begin{array}{l}\text { Mouse brain 1, } \\
\text { BHK2, Vero } 1\end{array}$ & S & $\underline{E F 485033}$ & [32] \\
\hline & & & M & EF485034 & \\
\hline & & & L & EF485035 & \\
\hline \multirow[t]{3}{*}{$\begin{array}{l}\text { Wisconsin/ } \\
\text { Human/1978-B }\end{array}$} & & $\begin{array}{c}\text { Mouse brain 1, } \\
\text { BHK2 }\end{array}$ & $S$ & NC004110 & \\
\hline & & & M & NC004109b & \\
\hline & & & L & NC004108b & \\
\hline $\begin{array}{l}\text { Rochester, MN/ } \\
\text { Mosquito/1978 }\end{array}$ & & Unknown & M & $\underline{\mathrm{DQ} 426680}$ & [33] \\
\hline $\begin{array}{l}\text { DeSoto, WI/ } \\
\text { Human/1978 }\end{array}$ & & $\begin{array}{c}\text { Suckling mice } 2, \\
\text { BHK } 2\end{array}$ & M & $\underline{\text { U18980 }}$ & [35] \\
\hline $\begin{array}{l}\text { Richland County, } \\
\text { WI/Mosquito/ } \\
1978\end{array}$ & & $\begin{array}{l}\text { Suckling mice 2, } \\
\text { BHK } 1\end{array}$ & M & $\underline{\text { U70206 }}$ & [36] \\
\hline
\end{tabular}


Table 3: Virus RNA sequences used in phylogenetic and molecular evolutionary analyses of virus isolates. (Continued)

\begin{tabular}{|c|c|c|c|c|}
\hline $\begin{array}{l}\text { North Carolina/ } \\
\text { Mosquito/1978-A }\end{array}$ & $\begin{array}{c}\text { Mouse brain 1, } \\
\text { Vero } 3\end{array}$ & $\mathrm{~S}$ & EF485036 & [33] \\
\hline & & $M$ & EF485037 & \\
\hline & & $\mathrm{L}$ & EF485038 & \\
\hline $\begin{array}{l}\text { North Carolina/ } \\
\text { Mosquito/1978-B }\end{array}$ & $\begin{array}{c}\text { Suckling mice } 2, \\
\text { Vero } 2\end{array}$ & $M$ & DQ426681 & [33] \\
\hline $\begin{array}{l}\text { Crawford County, } \\
\text { WI/Mosquito/ } \\
1979\end{array}$ & $\begin{array}{c}\text { Suckling mice 2, } \\
\text { BHK } 1\end{array}$ & $M$ & $\underline{\mathrm{U} 70207}$ & [36] \\
\hline $\begin{array}{l}\text { Washington } \\
\text { County, WI/ } \\
\text { Mosquito/1981 }\end{array}$ & $\begin{array}{c}\text { Suckling mice 2, } \\
\text { BHK } 1\end{array}$ & M & $\underline{\text { U70208 }}$ & [36] \\
\hline $\begin{array}{l}\text { Georgia/Canine/ } \\
1988\end{array}$ & $\begin{array}{c}\text { Veros } 1 \text {, Suckling } \\
\text { mice } 1\end{array}$ & $M$ & DQ426684 & [33] \\
\hline $\begin{array}{l}\text { Missouri/Human/ } \\
1993\end{array}$ & Vero 1 & M & $\underline{\text { U70205 }}$ & [36] \\
\hline $\begin{array}{l}\text { West Virginia/ } \\
\text { Mosquito/1995 }\end{array}$ & Vero 1 & $M$ & DQ426685 & [33] \\
\hline $\begin{array}{l}\text { North Carolina/ } \\
\text { Mosquito/1997 }\end{array}$ & Vero 1 & $M$ & DQ426686 & [33] \\
\hline $\begin{array}{l}\text { Tennessee/ } \\
\text { Mosquito/2000 }\end{array}$ & Vero 1 & $M$ & DQ426687 & [33] \\
\hline $\begin{array}{l}\text { Connecticut/ } \\
\text { Mosquito/2005 }\end{array}$ & Vero 1 & $M$ & $\underline{\mathrm{DQ} 426688}$ & [33] \\
\hline \multirow{3}{*}{$\begin{array}{l}\text { SVP/Vernon, Wl/ } \\
\text { Mosquito/2006 }\end{array}$} & Vero 2 & $\mathrm{~S}$ & GU596389 & \\
\hline & & $M$ & GU596384 & \\
\hline & & $\mathrm{L}$ & GU596378 & \\
\hline \multirow[t]{3}{*}{$\begin{array}{l}\text { NAT/Crawford, } \\
\text { WI/Mosquito/ } \\
2006\end{array}$} & Vero 2 & $\mathrm{~S}$ & GU596387 & \\
\hline & & $M$ & GU596382 & \\
\hline & & $\mathrm{L}$ & GU596379 & \\
\hline
\end{tabular}


Table 3: Virus RNA sequences used in phylogenetic and molecular evolutionary analyses of virus isolates. (Continued)

\begin{tabular}{|c|c|c|c|c|}
\hline \multirow[t]{2}{*}{$\begin{array}{l}\text { NAT/Crawford, } \\
\text { WI/Mosquito/ } \\
2007\end{array}$} & & \multirow[t]{2}{*}{ Vero 2} & \multirow{2}{*}{$\begin{array}{l}S \\
M\end{array}$} & \multirow{2}{*}{$\begin{array}{l}\text { GU596388 } \\
\text { GU596383 }\end{array}$} \\
\hline & & & & \\
\hline & & & L & GU596377 \\
\hline \multirow{3}{*}{$\begin{array}{l}\text { BEN2/Lafayette, } \\
\text { WI/Mosquito/ } \\
2007\end{array}$} & & Vero 2 & $\mathrm{~S}$ & GU596386 \\
\hline & & & M & GU596381 \\
\hline & & & L & GU596376 \\
\hline \multirow{3}{*}{$\begin{array}{l}\text { CAL-GA/Houston, } \\
\text { MN/Mosquito/ } \\
2007\end{array}$} & & Vero 2 & $\mathrm{~S}$ & GU596390 \\
\hline & & & M & GU596385 \\
\hline & & & L & GU596380 \\
\hline \multirow{2}{*}{$\begin{array}{l}\text { LAC01/SVP/ } \\
\text { LaCrosse, WI/ } \\
\text { Mosquito/2006A }\end{array}$} & $\mathrm{SI}+$ & Vero 1 & NSs & GU564182 \\
\hline & & & NSm & N/A \\
\hline \multirow{2}{*}{$\begin{array}{l}\text { LAC03/NAT/ } \\
\text { Crawford, WI/ } \\
\text { Mosquito/2007A }\end{array}$} & $\mathrm{SI}+$ & Vero 1 & NSs & $\underline{\text { GU564183 }}$ \\
\hline & & & NSm & GU564201 \\
\hline \multirow{2}{*}{$\begin{array}{l}\text { LAC05/KBT/ } \\
\text { Monroe, WI/ } \\
\text { Mosquito/2007A }\end{array}$} & I+ & None & NSs & GU564184 \\
\hline & & & NSm & GU564202 \\
\hline \multirow{2}{*}{$\begin{array}{l}\text { LAC06/GOLF/ } \\
\text { Houston, MN/ } \\
\text { Mosquito/2007A }\end{array}$} & I+ & None & NSs & GU564185 \\
\hline & & & $\mathrm{NSm}$ & $\underline{\text { GU564203 }}$ \\
\hline $\begin{array}{l}\text { LAC07/HIDV/ } \\
\text { Winona, MN/ } \\
\text { Mosquito/2007A }\end{array}$ & I+ & None & NSs & $\underline{\text { GU564186 }}$ \\
\hline
\end{tabular}


Table 3: Virus RNA sequences used in phylogenetic and molecular evolutionary analyses of virus isolates. (Continued)

\begin{tabular}{|c|c|c|c|c|}
\hline & & & $\mathrm{NSm}$ & $\underline{\text { GU564204 }}$ \\
\hline \multirow[t]{2}{*}{$\begin{array}{l}\text { LAC08/NAT/ } \\
\text { Crawford, WI/ } \\
\text { Mosquito/2007B }\end{array}$} & I+ & None & NSs & $\underline{\text { GU564187 }}$ \\
\hline & & & $\mathrm{NSm}$ & $\underline{\text { GU564205 }}$ \\
\hline \multirow[t]{2}{*}{$\begin{array}{l}\text { LAC09/HIDV/ } \\
\text { Winona, MN/ } \\
\text { Mosquito/2007B }\end{array}$} & $1+$ & None & NSs & GU564188 \\
\hline & & & $\mathrm{NSm}$ & $\underline{\text { GU564206 }}$ \\
\hline \multirow[t]{2}{*}{$\begin{array}{l}\text { LAC10/NAT/ } \\
\text { Crawford, WI/ } \\
\text { Mosquito/2007C }\end{array}$} & $\mathrm{I}+$ & None & NSs & GU564189 \\
\hline & & & $\mathrm{NSm}$ & GU564207 \\
\hline \multirow[t]{2}{*}{$\begin{array}{l}\text { LAC11/NAT/ } \\
\text { Crawford, WI/ } \\
\text { Mosquito/2007D }\end{array}$} & I+ & None & NSs & $\underline{\text { GU564190 }}$ \\
\hline & & & $\mathrm{NSm}$ & $\mathrm{N} / \mathrm{A}$ \\
\hline \multirow[t]{2}{*}{$\begin{array}{l}\text { LAC12/LCVP/ } \\
\text { Houston, MN/ } \\
\text { Mosquito/2007A }\end{array}$} & $1+$ & None & NSs & GU564191 \\
\hline & & & $\mathrm{NSm}$ & $\underline{\text { GU564208 }}$ \\
\hline \multirow[t]{2}{*}{$\begin{array}{l}\text { LAC13/ALP/ } \\
\text { LaCrosse, WI/ } \\
\text { Mosquito/2007A }\end{array}$} & $1+$ & None & NSs & GU564192 \\
\hline & & & $\mathrm{NSm}$ & $\underline{\text { GU564209 }}$ \\
\hline \multirow[t]{2}{*}{$\begin{array}{l}\text { LAC14/DAKE/ } \\
\text { Winona, MN/ } \\
\text { Mosquito/2007A }\end{array}$} & I+ & None & NSs & GU564193 \\
\hline & & & $\mathrm{NSm}$ & $\underline{\text { GU564210 }}$ \\
\hline \multirow[t]{2}{*}{$\begin{array}{l}\text { LAC16/NAT/ } \\
\text { Crawford, WI/ } \\
\text { Mosquito/2007B }\end{array}$} & $\mathrm{SI}+$ & None & NSs & GU564194 \\
\hline & & & $\mathrm{NSm}$ & GU564211 \\
\hline
\end{tabular}


Table 3: Virus RNA sequences used in phylogenetic and molecular evolutionary analyses of virus isolates. (Continued)

\begin{tabular}{|c|c|c|c|c|}
\hline $\begin{array}{l}\text { LAC19/BEN2/ } \\
\text { Lafayette, WI/ } \\
\text { Mosquito/2007D }\end{array}$ & $\mathrm{SI}+$ & None & NSs & $\underline{\text { GU564195 }}$ \\
\hline & & & $\mathrm{NSm}$ & GU564212 \\
\hline \multirow[t]{2}{*}{$\begin{array}{l}\text { LAC20/BEN2/ } \\
\text { Lafayette, WI/ } \\
\text { Mosquito/2007E }\end{array}$} & $\mathrm{SI}+$ & None & NSs & GU564196 \\
\hline & & & $\mathrm{NSm}$ & GU564213 \\
\hline \multirow[t]{2}{*}{$\begin{array}{l}\text { LAC21/BEN2/ } \\
\text { Lafayette, WI/ } \\
\text { Mosquito/2007F }\end{array}$} & $\mathrm{SI}+$ & None & NSs & GU564197 \\
\hline & & & $\mathrm{NSm}$ & GU564214 \\
\hline \multirow[t]{2}{*}{$\begin{array}{l}\text { LAC22/CAL-GA/ } \\
\text { Houston, MN/ } \\
\text { Mosquito/2007G }\end{array}$} & $\mathrm{SI}+$ & Vero 1 & NSs & $\underline{\text { GU564198 }}$ \\
\hline & & & $\mathrm{NSm}$ & GU564215 \\
\hline \multirow[t]{2}{*}{$\begin{array}{l}\text { LAC23/CAL-GA/ } \\
\text { Houston, MN/ } \\
\text { Mosquito/2007J }\end{array}$} & $\mathrm{SI}+$ & Vero 1 & NSs & $\underline{\text { GU564199 }}$ \\
\hline & & & $\mathrm{NSm}$ & GU564216 \\
\hline \multirow[t]{2}{*}{$\begin{array}{l}\text { LAC24/CAL-GA/ } \\
\text { Houston, MN/ } \\
\text { Mosquito/2007K }\end{array}$} & $\mathrm{SI}+$ & Vero 1 & NSs & GU564200 \\
\hline & & & $\mathrm{NSm}$ & GU564217 \\
\hline $\begin{array}{l}\text { LAC27/CAL-GA/ } \\
\text { Houston, MN/ } \\
\text { Mosquito }\end{array}$ & I+ & None & $\mathrm{NSm}$ & GU564218 \\
\hline $\begin{array}{l}\text { LAC28/CAL-GA/ } \\
\text { Houston, MN/ } \\
\text { Mosquito }\end{array}$ & I+ & None & $\mathrm{NSm}$ & GU564219 \\
\hline $\begin{array}{l}\text { LAC29/CAL-GA/ } \\
\text { Houston, MN/ } \\
\text { Mosquitor }\end{array}$ & I+ & None & $\mathrm{NSm}$ & GU564220 \\
\hline
\end{tabular}



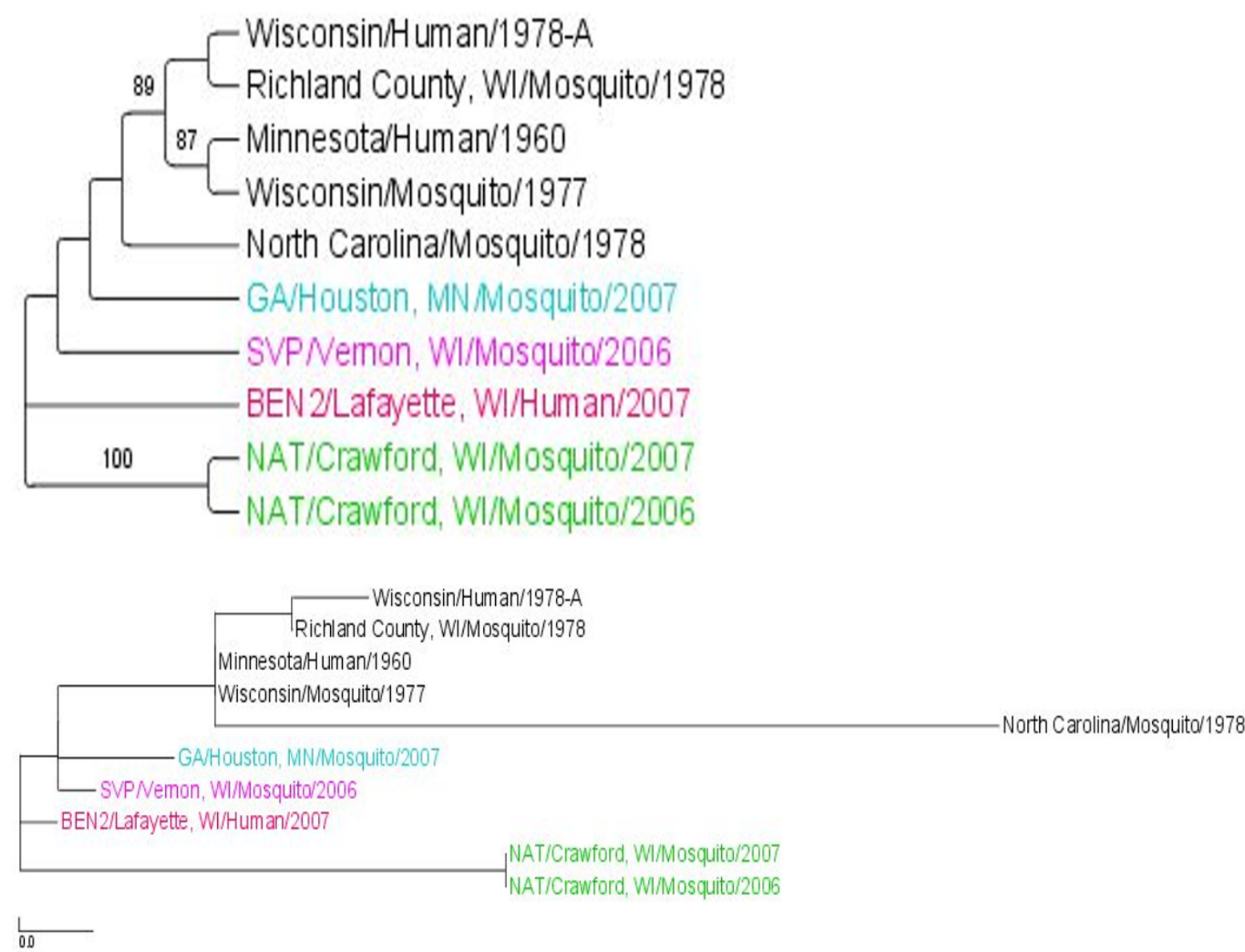

Figure 3 Maximum Likelihood (ML) tree derived for the LACV S segment using RAxML. The top figure is a cladogram; numbers over branches indicate \% bootstrap support. The bottom figure is a phylogram. Length of scale bar $=0.01$. Colored branches correspond to sites in Figure 1 .

ment analysis, it is in a clade with all the LACV isolates from Wisconsin and Minnesota, whereas in the L segment analysis the isolate is in a clade with the isolates from NAT/Crawford, WI/2006 and/2007. This is likely evidence for segment reassortment.

\section{Phylogenetic analysis of the NSs and NSm genes from $\mathrm{SI}+$ and $\mathrm{I}+$ mosquitoes}

The multiple functions of the NSs (S segment) and NSm (M segment) proteins in the viral life cycle make these proteins strong candidates for conditioning the I+ and $\mathrm{SI}+$ phenotypes. To examine this hypothesis, LACV NSs and NSm genes from 8-12 mosquitoes of both phenotypes were sequenced and compared in an effort to correlate the $\mathrm{SI}+/ \mathrm{I}+$ phenotypes with nucleotide and/or amino acid differences. NSm genes were also sequenced from $\mathrm{SI}+$ and I+ mosquitoes collected from the same locations in the same year. NSs and NSm nucleotide sequences were deposited in GenBank (Table 3).
NSs sequences were determined for $10 \mathrm{I}+$ amplicons and nine SI+ isolates collected in 2006 and 2007. No NSs nucleotide differences were observed among the nineteen isolates (Additional File - Figure 1). This analysis was repeated with the NSm gene and the same phylogenetic patterns as described for the $\mathrm{S}, \mathrm{M}$, and $\mathrm{L}$ segments were noted (Figure 6). SI+ isolates are polyphyletic. Note that despite the similarity of the $M$ segments from NAT/ Crawford SI+ isolates (Figure 4), these isolates are very genetically distinct from all other isolates.

\section{Molecular evolution of LACV isolates and NSm sequences}

The number of segregating sites $(\mathrm{S})$, unique haplotypes (Hap), and singletons $\eta_{\mathrm{e}}$ for each gene in SI+ and previously published LACV isolates and between NSm sequences from I+ and SI+ mosquitoes are listed in Table 4. Also listed are overall nucleotide diversity $(\pi), \pi_{\mathrm{s}}$ among synonymous sites and $\pi_{\mathrm{a}}$ among replacement sites 

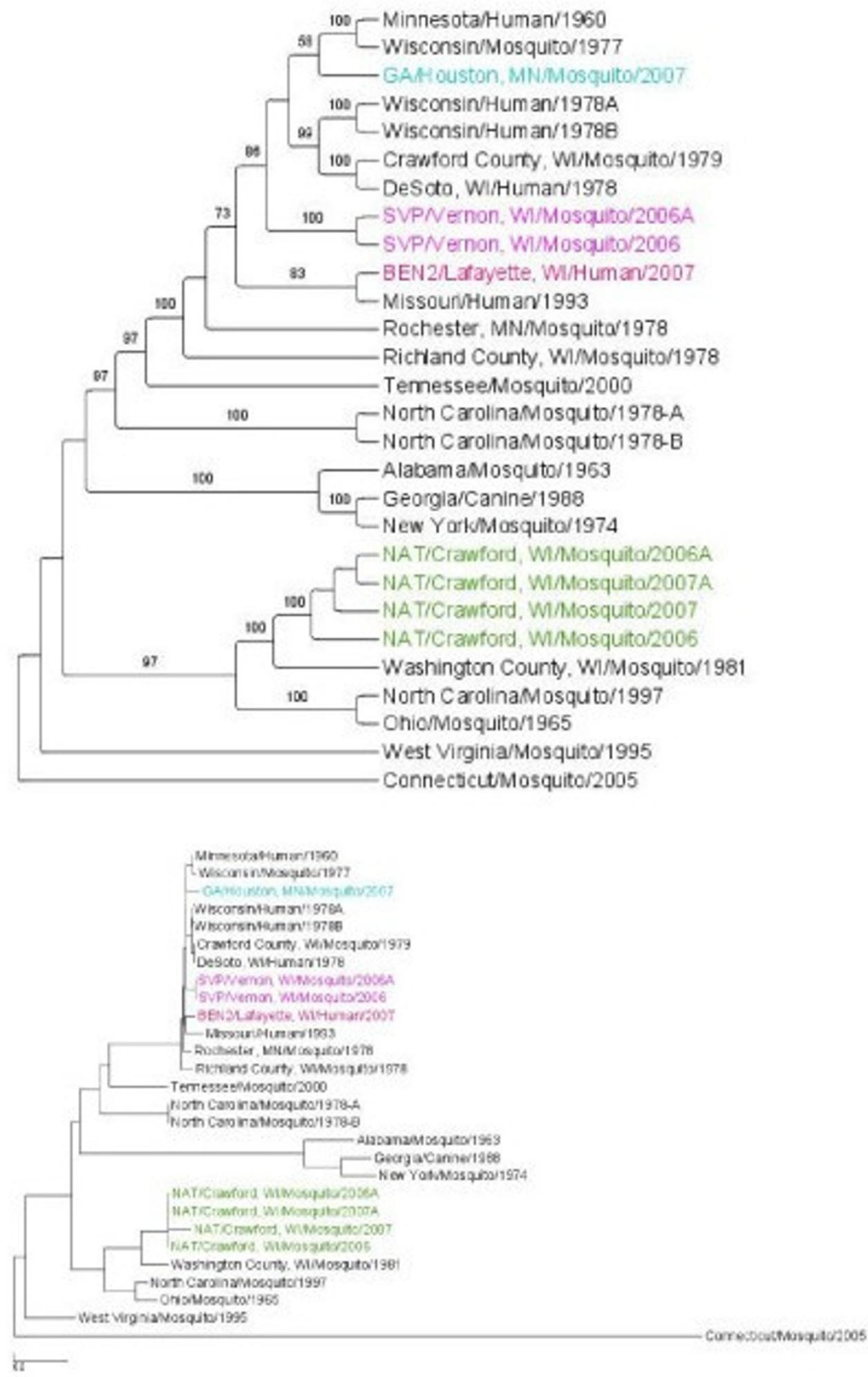

Figure 4 Maximum Likelihood (ML) tree derived for the LACV M segment using RAxML. The top figure is a cladogram; numbers over branches indicate $\%$ bootstrap support. The bottom figure is a phylogram. Length of scale bar $=0.01$. Colored branches correspond to sites in Figure 1 . 

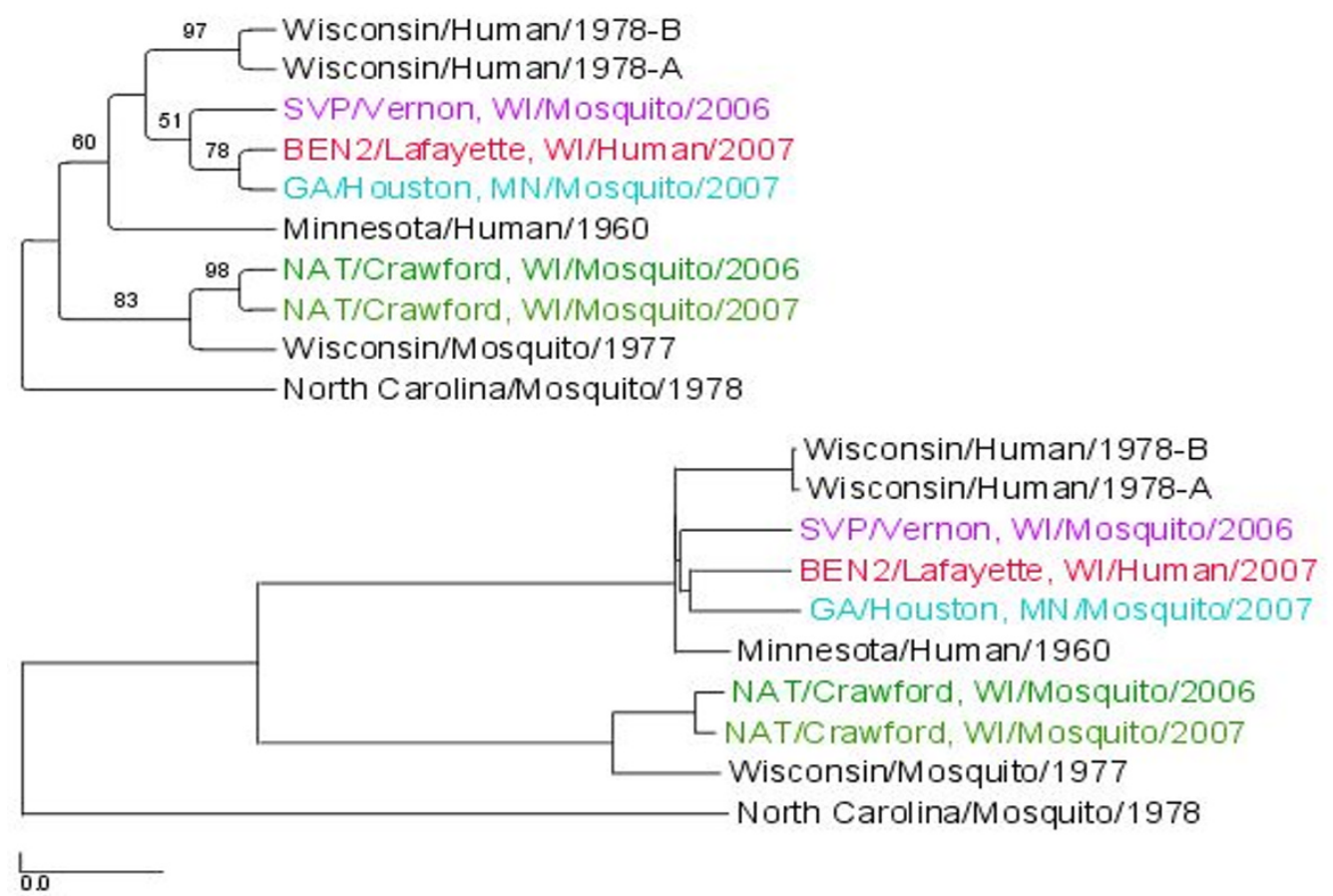

\footnotetext{
I+/NAT/Crawford, WI/2007b

SI+/CAL-GA/Houston, MN/2007J

-SI+/CAL-GA/Houston, MN/2007G

SI+/CAL-GA/Houston, MN/2007K -I+/ALP/La Crosse, WI/2007

I+/DAKE/Winona, MN/2007

-I+/CAL-GA/Houston, MN/2007a

I+/CAL-GA/Houston, MN/2007b

I+/CAL-GA/Houston, MN/2007C

SI+/BEN2/Layfayette, Wl/2007D

SI+/BEN2/Layfayette, WI/2007F

SI+/BEN2/Layfayette, WI/2007E
}

Lo

Figure 5 Maximum Likelihood (ML) tree derived for the LACV L segment using RAxML. The top figure is a cladogram; numbers over branches indicate \% bootstrap support. The bottom figure is a phylogram. Length of scale bar $=0.01$. Colored branches correspond to sites in Figure 1 .

in the 6 protein encoding genes. Theta from pair-wise comparisons and $\mathrm{F}^{*}$ are also listed.

Table 4 indicates five patterns. First, the numbers of segregating sites are consistently larger in previously published isolates as compared to SI+ isolates (1.3, 2.2 and 1.6 fold higher in the S, M, and L segments, respectively). The only exception was seen in the NSm gene where there were 37 segregating sites among SI+ isolates as compared with five sites in previously published isolates. Similarly, the expected numbers of segregating sites $(\theta)$ are consistently larger in previously published isolates (1.3, 1.8 and 1.6 fold higher in the S, M, and L segments respectively) but 8 fold higher in the NSm gene in $\mathrm{SI}+$ as compared with previously published isolates. Second, the numbers of singletons were much larger in previously published isolates $(4.2,12.4$ and 3.6 fold higher in the $S$, $\mathrm{M}$, and L segments, respectively) as compared with the $\mathrm{SI}+$ isolates. This trend was especially pronounced in the $\mathrm{NSm}$ gene in SI+ isolates. Despite having 37 segregating sites, none of these were singletons in SI+ but four of the 

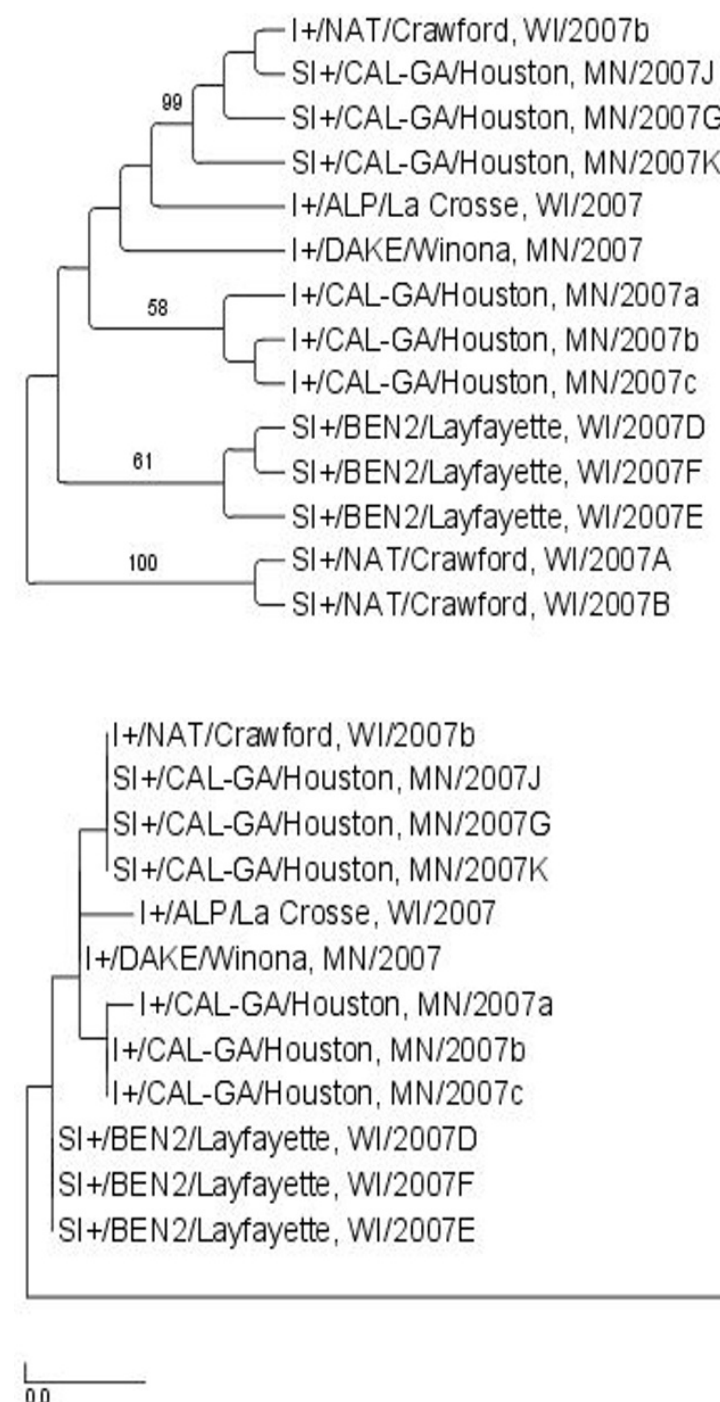

I+/NAT/Crawford, WI/2007b

SI+/CAL-GA/Houston, MN/2007J

SI+/CAL-GA/Houston, MN/2007G

SI+/CAL-GA/Houston, MN/2007K

I+/ALP/La Crosse, WI/2007

+/DAKE/Winona, MN/2007

- I+/CAL-GA/Houston, MN/2007a

I+/CAL-GA/Houston, MN/2007b

I+/CAL-GA/Houston, MN/2007C

SI+/BEN2/Layfayette, WI/2007D

SI+/BEN2/Layfayette, WI/2007F

SI+/BEN2/Layfayette, WI/2007E

Figure 6 Maximum Likelihood (ML) tree derived for the LACV NSm sequence of SI+ and I+ mosquitoes using RAxML. The top figure is a cladogram; numbers over branches indicate \% bootstrap support. The bottom figure is a phylogram. Length of scale bar $=0.01$. Colored branches correspond to sites in Figure 1.

five sites were singletons in previously published isolates. Third, the three measures of nucleotide diversity $(\pi)$ did not differ greatly between previously published and SI+ isolates. Diversity was greatest in the M segment and least in the $\mathrm{S}$ segment. The only exception was again seen in the NSm gene where there was 9 fold greater $\pi$ among $\mathrm{SI}+$ isolates as compared with I+ isolates. Fourth, the ratio $\pi_{a} / \pi_{s}$ was small in all comparisons indicating that the majority of mutations are synonymous and the rate of amino acid evolution is slow. Fifth, and most noteworthy, $\mathrm{F}^{*}$ was consistently positive among SI+ isolates and consistently negative among previously published isolates in all three segments and in the NSm gene. However, this difference was most pronounced (and significant) in the M segment, particularly in the G2 and NSm genes. This difference is most obvious when $\mathrm{F}^{*}$ is plotted separately for SI+ and previously published isolates across the entire genome (Figure 7a) and between $\mathrm{SI}+$ and I+ in the NSm gene (Figure 7b).

Relative Synonymous Codon Usage (RSCU) was analyzed within and among I+ and SI+ isolates using the GCUA (General Codon Usage Analysis) package [35]. Clusters as revealed by correspondence analysis, principal components analysis and cluster based upon McIner- 
Table 4: Molecular evolution rates ${ }^{a}$ among LACV isolates and NSm genes from SI+ and I+ mosquitoes.

\begin{tabular}{|c|c|c|c|c|c|c|c|c|c|c|}
\hline Domain & Sites & $\mathbf{S}$ & Hap & $\eta \varepsilon$ & $\pi$ & $\pi \sigma$ & $\pi a$ & $\pi \alpha / \pi \sigma$ & $\theta$ & $\mathbf{F}^{*}$ \\
\hline \multicolumn{11}{|l|}{ S segment } \\
\hline \multicolumn{11}{|l|}{$\mathrm{SI}+$ isolates } \\
\hline $\begin{array}{l}\text { 5' S non-coding } \\
\text { (nt 1-81) }\end{array}$ & 81 & 2 & 3 & 0 & 0.0124 & & & & 0.96 & 0.2386 \\
\hline $\begin{array}{l}\text { Nucleocapsid } \\
\text { (nt 82-789) }\end{array}$ & 708 & 11 & 4 & 2 & 0.0088 & 0.0378 & 0.0000 & - & 5.28 & 1.3261 \\
\hline NSs (nt 102-379) & 278 & 0 & 1 & 1 & 0.0000 & 0.0000 & 0.0000 & - & 0.01 & - \\
\hline $\begin{array}{l}\text { 3' S non-coding } \\
\text { (nt 787-984) }\end{array}$ & 195 & 5 & 4 & 2 & 0.0133 & & & & 2.40 & 0.5779 \\
\hline All & 984 & 18 & 11 & 5 & 0.0100 & & & & 8.64 & 1.0574 \\
\hline \multicolumn{11}{|l|}{ Previous isolates } \\
\hline $5^{\prime}$ & & 1 & 2 & 1 & 0.0059 & & & & 0.48 & -0.7715 \\
\hline Nucleocapsid & & 13 & 3 & 11 & 0.0088 & 0.0378 & 0.0000 & - & 6.24 & -0.7910 \\
\hline NSs & & 1 & 2 & 0 & 0.0017 & 0.0108 & 0.0000 & - & 0.48 & 1.1573 \\
\hline $3^{\prime}$ & & 9 & 3 & 9 & 0.0222 & & & & 4.32 & -1.2451 \\
\hline All & & 23 & 4 & 21 & 0.0098 & & & & 11.04 & -1.0400 \\
\hline \multicolumn{11}{|l|}{ M segment } \\
\hline \multicolumn{11}{|l|}{$\mathrm{SI}+$ isolates } \\
\hline $\begin{array}{l}\text { 5' M non-coding } \\
\text { (nt } 1-61 \text { ) }\end{array}$ & 61 & 1 & 2 & 0 & 0.0094 & & & & 0.41 & 1.1015 \\
\hline G2 (nt 62-961) & 900 & 44 & 4 & 3 & 0.0267 & 0.1007 & 0.0041 & 0.0411 & 17.96 & $1.7100^{*}$ \\
\hline NSm (nt 962-1483) & 522 & 37 & 4 & 1 & 0.0400 & 0.1626 & 0.0056 & 0.0344 & 15.10 & $1.8884^{* *}$ \\
\hline G1 (nt 1484-4388) & 2905 & 190 & 7 & 25 & 0.0346 & 0.1406 & 0.0041 & 0.0292 & 77.55 & 1.4902 \\
\hline $\begin{array}{l}\text { 3' M non-coding } \\
\text { (nt 4389-4526) }\end{array}$ & 138 & 17 & 6 & 7 & 0.0549 & & & & 6.94 & 0.3115 \\
\hline Total & 4526 & 289 & 7 & 36 & 0.0339 & & & & 117.96 & 1.5238 \\
\hline \multicolumn{11}{|l|}{ Previous Isolates } \\
\hline $5^{\prime}$ & & 3 & 3 & 3 & 0.0089 & & & & 1.02 & -2.0309 \\
\hline $\mathrm{G} 2$ & & 104 & 8 & 79 & 0.0287 & 0.1040 & 0.0060 & 0.0574 & 36.87 & -1.7512 \\
\hline NSm & & 80 & 8 & 57 & 0.0373 & 0.1303 & 0.0111 & 0.0851 & 28.00 & -1.6129 \\
\hline G1 & & 421 & 9 & 296 & 0.0361 & 0.1378 & 0.0068 & 0.0492 & 145.79 & -1.5991 \\
\hline $3^{\prime}$ & & 14 & 5 & 13 & 0.0225 & & & & 5.12 & -2.1718 \\
\hline & & 622 & 9 & 448 & 0.0340 & & & & 216.80 & -1.6626 \\
\hline
\end{tabular}

L segment

$\mathrm{SI}+$ isolates

\begin{tabular}{|c|c|c|c|c|c|c|c|c|c|c|}
\hline $\begin{array}{l}\text { 5' L non-coding } \\
\text { (nt 1-61) }\end{array}$ & 61 & 2 & 3 & 0 & 0.0197 & & & & 0.96 & 1.4316 \\
\hline RNA polymerase & 6789 & 249 & 5 & 79 & 0.0197 & 0.0878 & 0.0016 & 0.0179 & 119.52 & 0.9799 \\
\hline
\end{tabular}


Table 4: Molecular evolution rates ${ }^{\mathrm{a}}$ among LACV isolates and NSm genes from SI+ and I+ mosquitoes. (Continued)

\begin{tabular}{|c|c|c|c|c|c|c|c|c|c|c|}
\hline $\begin{array}{l}\text { 3' non-coding (nt } \\
12361-12490)\end{array}$ & 131 & 6 & 4 & 3 & 0.0260 & & & & 3.36 & 0.4325 \\
\hline Total & 6980 & 257 & 5 & 82 & 0.0198 & & & & 123.84 & 0.9754 \\
\hline \multicolumn{11}{|l|}{ Previous isolates } \\
\hline $5^{\prime}$ & & 4 & 4 & 3 & 0.0295 & & & & 1.92 & -0.4175 \\
\hline RNA polymerase & & 398 & 5 & 288 & 0.0270 & 0.1204 & 0.0021 & 0.0177 & 192.96 & -0.4076 \\
\hline $3^{\prime}$ & & 6 & 5 & 2 & 0.0244 & & & & 2.88 & 0.7913 \\
\hline Total & & 408 & 5 & 293 & 0.0270 & & & & 197.76 & -0.3893 \\
\hline \multicolumn{11}{|l|}{ NSm gene } \\
\hline $\mathrm{SI}+$ mosquitoes & 522 & 37 & 3 & 0 & 0.0308 & 0.1257 & 0.0042 & 0.0334 & 16.0710 & $1.5685^{*}$ \\
\hline I+ mosquitoes & & 5 & 5 & 4 & 0.0037 & 0.0140 & 0.0008 & 0.0587 & 1.9330 & -0.8121 \\
\hline
\end{tabular}

a Sites $=$ number of nucleotides in each gene or segment region. $S=$ number of segregating sites. Hap = number of distinct haplotypes. $\eta_{e}=$ number of singletons, $\pi=$ nucleotide diversity, the average number of nucleotide differences per site between two sequences, $\pi_{s}=$ nucleotide diversity among synonymous sites, $\pi_{s}=$ nucleotide diversity among replacement sites, $\theta=E\left(\pi\right.$ expected number of pairwise differences in $S$, $F^{*}$ $=\mathrm{Fu}$ and $\mathrm{Li}(1993) .{ }^{*}\left|\mathrm{~F}^{*}\right|>0$ with probability of $0.05,{ }^{* *}\left|\mathrm{~F}^{*}\right|>0$ with probability of 0.01

ney's distance measure completely overlapped between SI+ and previously published isolates indicating no general differential RSCU between the groups.

\section{Nucleotide differences between LACV SI+ and previously published isolates and between LACV NSm sequences from $\mathrm{I}+$ and $\mathrm{SI}+$ mosquitoes}

The number of net nucleotide substitution differences/ site $\left(\mathrm{D}_{\mathrm{a}}=\mathrm{D}_{\mathrm{I}+\mathrm{SI}+}-\left(\left(\mathrm{D}_{\mathrm{I}+}+\mathrm{D}_{\mathrm{SI}+}\right) / 2\right)\right)$ [36]) between LACV isolates from $\mathrm{SI}+$ and previously published LACV sequences were plotted for each site in the three segments (Figure 8a), and for the NSm gene from SI+ and I+ mosquitoes (Figure $8 \mathrm{~b}$ ) to test for large nucleotide differences. Figure 8a clearly indicates that the majority of differences arise on the $M$ segment. Table 5 lists the nucleotides at each site with a $\mathrm{D}_{\mathrm{a}}>0.1$. These appear as nucleotides in non-coding regions or as codons in the protein coding regions. The RSCU for the LACV isolates are listed for each substitution. RSCU values that differed by $>0.1$ between the $\mathrm{SI}+$ and previously published isolates are grey highlighted. The average RSCU for SI+ isolates and previously published isolates appear at the bottom of the table. All of the substitutions with $D_{a}>0.1$ were synonymous. A pair-wise t-test of differences in RSCU between SI+ and previously published isolates was performed and was not significant.

In the overall analysis, a single large difference was detected in NSm gene sequences from SI+ and I+ mosquitoes. The QTN identified in position 246 of the NSm gene (Figure $8 \mathrm{~b}$ ) corresponds to a $\mathrm{U}$ to $\mathrm{A}$ transversion in the third position of a CUN Leu codon. This codon shows severe bias towards CUU (57 codons in 14 mosquitoes) compared to a CUA (7 codons in 14 mosquitoes). All 7
CUA codons appeared in SI+ mosquitoes but none appeared in the I+ mosquitoes. The difference was significant using Fisher's exact test $(\mathrm{P}$-value $=0.01437)$.

\section{LACV NSm nucleotide and amino acid differences between LACV SI+ and I+ mosquitoes from one site}

Two SI+ and two I+ mosquitoes, respectively, were detected at the NAT site (Figure 9). The SI+ and I+ sequences differed in numerous nts (Figure 9a). Four LACV NSm amino acids differentiated the two SI+ mosquitoes (NAT/Crawford, WI, NAT/2007A and NAT/ 2007B) from the two I+ mosquitoes (I+/NAT/Crawford, $\mathrm{WI} / 2008 \mathrm{a}$ ) and I+/NAT/Crawford, WI/2008b) (Figure 9b). These four amino acid changes: D43E, L60F, I79T, and A132T provide possible molecular correlates of I+ vs. $\mathrm{SI}+$ phenotype. In contrast, the LACV NSs sequences of the four mosquitoes were absolutely conserved (Additional Files - Figure 1).

\section{Discussion}

The detection of SI+ in addition to I+ mosquitoes (Figure 2) was surprising. I+ mosquitoes were only detected because we assayed individual mosquitoes by IFA and PCR. They did not yield infectious virus and would not be detected by cell culture bioassay [33]. I+ mosquitoes are $>10$-fold more common in nature than SI+ mosquitoes, and thus could pose a significant risk to humans (Table 1). When first detected, we thought I+ mosquitoes might be a laboratory artifact resulting from less than optimal collecting and processing conditions, which could have reduced virus stability, infectivity, and titer, resulting in the I+ phenotype. However, the finding was replicated in multiple years. I+ mosquitoes may have low 
titer infections in certain organs and tissues that could be rescued by environmental and physiological stimuli. For example, isolation of St. Louis encephalitis and West Nile viruses from overwintering mosquitoes $[37,38]$ is enhanced when field collected Culex pipiens mosquitoes are held at ambient insectary temperatures and provided sugar meals before virus assay. However, I+ mosquitoes were hatched and reared to adults in the insectary before virus assay, which would have provided ample time and metabolic and cellular activity for LACV to replicate to detectable titer. Perhaps additional physiological stimuli (e.g., mating, oogenesis, gonadotrophic cycles) would rescue infectious virus from I+ mosquitoes. The sensitivity of virus isolation by cell culture bioassay may also be a confounding factor. In early studies, virus was isolated by inoculation of samples into suckling mice [5,7], which is more sensitive than virus isolation in cell culture [33]. However, the equally sensitive method of intrathoracic inoculation of Ae. triseriatus mosquitoes also failed to yield infectious virus (data not shown). These observations suggest that I+ mosquitoes represent non-productive or abortive infections of the mosquito. The I+ mosquitoes must be controlling or clearing the infection. If so, they could yield critical and fundamental information concerning the molecular, immunologic, and physiological bases of vector competence.

The SI+ mosquitoes are also of great interest. If they are stably-infected, a relatively small number of these females could maintain LACV in nature with a low general field infection rate [18]. SI+ mosquitoes were detected in the population at a low level (prevalence rate $=0.0009$ ) (Table 1) but were widely distributed in the collection area (Figure 1). The prevalence of SI+ mosquitoes ranged from 0.0084 (NAT/Crawford County, WI/2007) to 0.12 (CALGA/Houston, MN/2007) (Table 2). The identification of $\mathrm{SI}+$ mosquitoes in the same NAT site in two different years suggests that LACV is stabilized in mosquitoes in this collection site. Stabilized infection of D. melanogaster with SIGMAV occurs when the germarium of females become infected $[16,17]$, resulting in virus TOT to nearly $100 \%$ of progeny. A relatively low number of stably-infected females can maintain SIGMAV at a low prevalence indefinitely in nature $[39,40]$. Studies are needed to determine if LACV infects the germarium of SI+ mosquitoes and is passed to all or most progeny in ensuing generations.

This also raises the question of whether individual mosquito families or populations are responsible for the SI+ phenotype or whether some LACV quasispecies arise by accident or at random in particular populations, and cause SI+ infections in mosquitoes in geographic islands. There is significant gene flow in Ae. triseriatus populations [41] including in our study area in the LaCrosse region [42]. Nonetheless, it is possible that in geographic islands an innate immune arms race could emerge between the virus and the vector resulting in stabilized infection.

Our molecular evolutionary analyses strongly argue that $\mathrm{SI}+$ quasispecies evolve at random in particular breeding sites or geographic islands. SI+ isolates are phylogenetically similar but are polyphyletic. Synonymous substitution rates greatly exceeded replacement rates in all genes and isolates. Overall, no general differences in RSCU were detected between previously published and $\mathrm{SI}+$ isolates. However, the overall comparison of the LACV NSm gene from I+ and SI+ mosquitoes did identify a single QTN (U A transversion) in a Leu (CUN) codon in the NSm gene (Figure $8 \mathrm{~b}$ ). The significance of this QTN remains to be determined.

A consistent and significant trend was detected by $\mathrm{Fu}$ and Li's $\mathrm{F}^{*}$ analysis of singleton versus shared mutations (Figure 8a) and in direct comparison of I+ and SI+ mosquitoes (Figure $8 \mathrm{~b}$ ). S and L segments evolved in a manner consistent with purifying selection and subsequent neutralism. But the SI+ M segment had a large and significant excess of intermediate-frequency alleles while the $M$ segment had a large, significant excess of singletons in previously published LACV sequences and in sequences from I+ mosquitoes. It is difficult to make any definite conclusions from the previously published sequences, which were collected over a period of 45 years and did not arise from an intensive spatial or temporal field sample. Thus, the chances of finding intermediate frequency $\eta_{\mathrm{i}}$ alleles is small. Nevertheless, Figures 7a and 8a illustrate that most of the evolution of the past 45 years has occurred in the $\mathrm{M}$ segment.

The patterns in direct comparison of NSm sequences from I+ and SI+ mosquitoes in Figures $7 \mathrm{~b}$ and $8 \mathrm{~b}$ are consistent with an hypothesis that the error prone RNAdependent RNA polymerase generates a constellation of genotypes and the majority of these generate I+ phenotypes in their mosquito host. The large accumulation of singletons in $\mathrm{I}+$ isolates in third codon positions reflect the activity of error prone RNA-dependent RNA polymerase, filtered by purifying selection. In contrast, occasionally a SI+ genotype arises and, because they survive and are maintained at a higher rate in stably-infected mosquito lineages than I+ genotype, SI+ maintain an excess of intermediate-frequency $\eta_{i}$ alleles. These intermediate-frequency alleles may confer reduced detection and/or destruction via the RNAi or apoptotic/autophagic pathways. Disruptive selection would then increase to moderate frequencies those genotypes that avoided destruction in the mosquito host and become manifested as SI+ mosquitoes. A much larger proportion of novel gene sequences in the $M$ segment would yield viable virus but which would only partially avoid detection and/or destruction. Selection would not increase the frequencies 
A. Whole genome

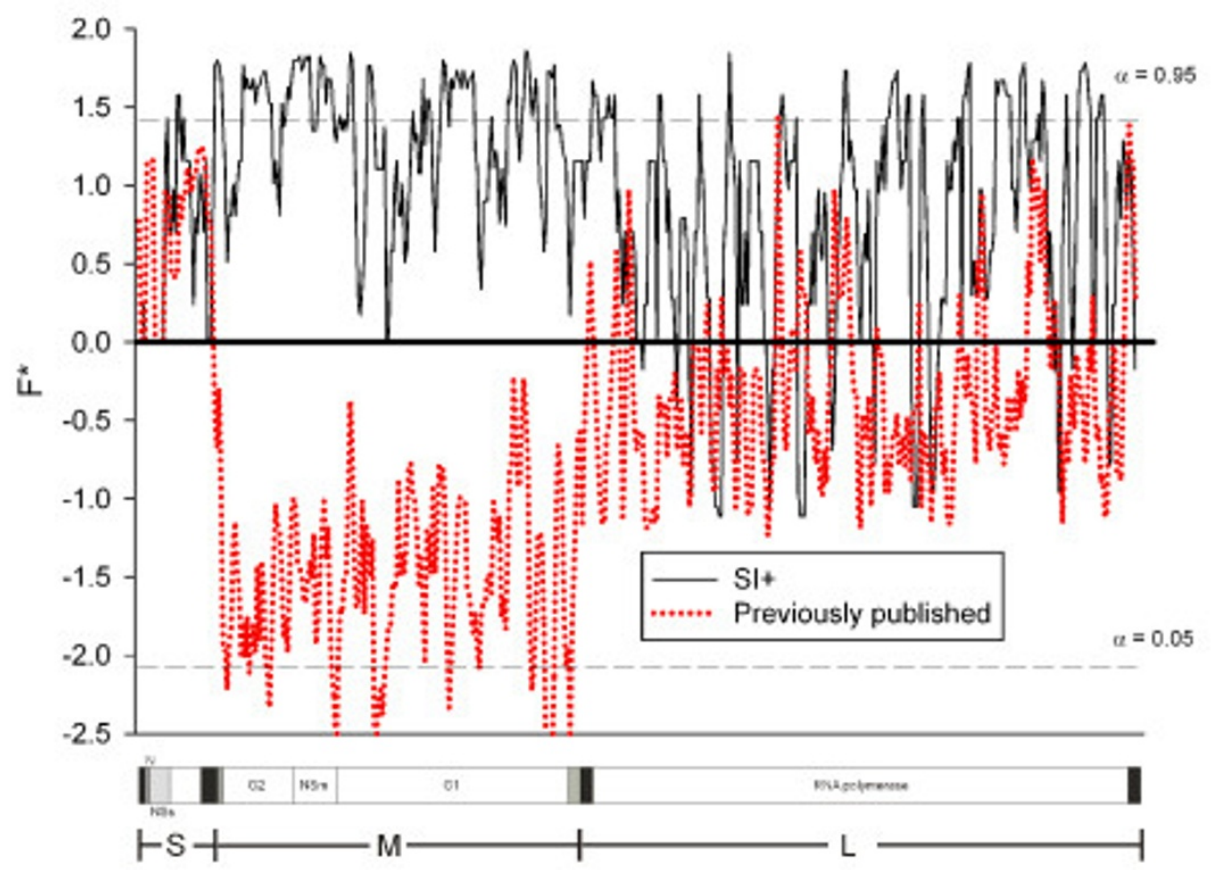

b. NSm gene

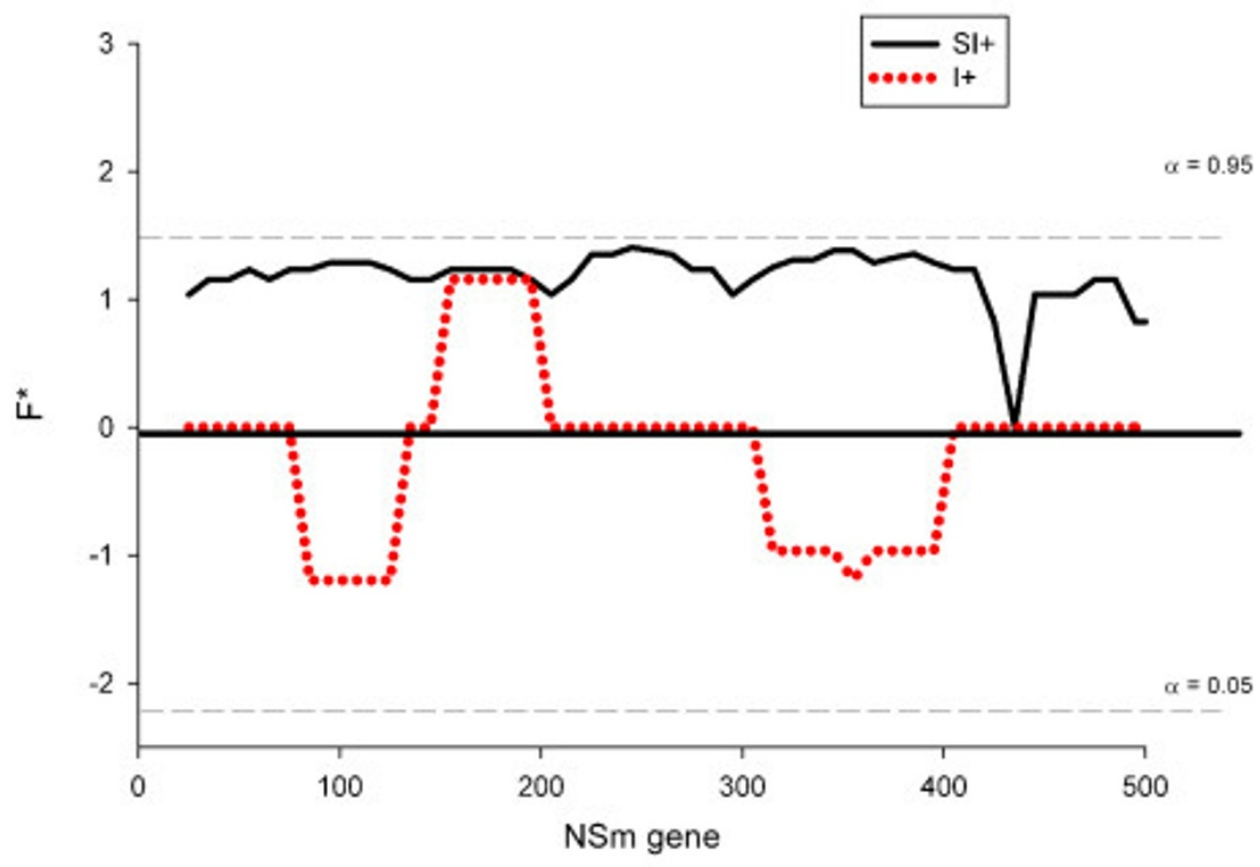

Figure 7 Molecular evolution of LACV: Comparison of segregating sites, haplotypes, and singletons between the three RNA segments of $\mathrm{SI}+$ isolates and previously published isolates (7a) and between NSm genes from I+ and $\mathrm{SI}+$ mosquitoes (7b). 
Table 5: Substitutions that differ in frequency between $\mathrm{SI}+$ and previous isolates with $\mathrm{Da}>\mathbf{0 . 1 0}$.

\begin{tabular}{|c|c|c|c|c|c|c|}
\hline $\begin{array}{l}\text { Genome } \\
\text { Region }\end{array}$ & & $\mathrm{Da}$ & $\begin{array}{c}\text { SI+ } \\
\text { codon }\end{array}$ & $\begin{array}{c}\text { Prev. publ. } \\
\text { Codon }\end{array}$ & $\begin{array}{c}\text { RSCU } \\
\text { SI+ }\end{array}$ & $\begin{array}{c}\text { RSCU } \\
\text { Prev. publ. }\end{array}$ \\
\hline \multicolumn{7}{|l|}{ M segment } \\
\hline \multicolumn{7}{|l|}{ 5' noncoding } \\
\hline 42 & $5^{\prime} \mathrm{NC}$ & 0.143 & A & G & - & - \\
\hline \multicolumn{7}{|l|}{$\mathrm{G} 2$} \\
\hline 478 & Val & 0.143 & GUA & GUG & 0.254 & 0.210 \\
\hline 658 & $\mathrm{Gln}$ & 0.143 & CAA & CAG & 0.540 & 0.460 \\
\hline 697 & Leu & 0.143 & UUG & UUA & 0.233 & 0.300 \\
\hline \multicolumn{7}{|l|}{ NSm } \\
\hline 991 & Ile & 0.143 & AUU & $A \cup A$ & 0.287 & 0.544 \\
\hline 1204 & Leu & $-0.027-0.357$ & CUA & CUU & 0.177 & 0.116 \\
\hline 1207 & Phe & 0.143 & UUC & UUU & 0.453 & 0.547 \\
\hline 1288 & Leu & 0.143 & UUA & UUG & 0.300 & 0.233 \\
\hline 1306 & Phe & 0.143 & UUU & UUC & 0.547 & 0.453 \\
\hline 1327 & Cys & 0.143 & UGU & UGC & 0.472 & 0.528 \\
\hline \multicolumn{7}{|l|}{ G1 } \\
\hline 1501 & Thr & 0.143 & $\mathrm{ACU}$ & $\mathrm{ACC}$ & 0.316 & 0.173 \\
\hline 1543 & Pro & 0.182 & CCG & CCA & 0.054 & 0.492 \\
\hline 1639 & Leu & 0.143 & CUG & CUA & 0.114 & 0.177 \\
\hline 1690 & Arg & 0.143 & AGG & AGA & 0.422 & 0.578 \\
\hline 1951 & Gly & 0.143 & GGA & GGG & 0.288 & 0.114 \\
\hline 1984 & Leu & 0.143 & CUG & CUA & 0.114 & 0.177 \\
\hline 2002 & His & 0.143 & CAC & CAU & 0.354 & 0.646 \\
\hline 2584 & Gly & 0.143 & GGA & GGG & 0.288 & 0.274 \\
\hline 2929 & Pro & 0.182 & CCA & CCG & 0.492 & 0.054 \\
\hline 3169 & Lys & 0.143 & AAG & AAA & 0.381 & 0.619 \\
\hline 3214 & His & 0.143 & CAC & CAU & 0.354 & 0.646 \\
\hline 3310 & Gly & 0.182 & GGA & GGG & 0.288 & 0.274 \\
\hline 3754 & Val & 0.143 & GUA & GUG & 0.254 & 0.210 \\
\hline 3916 & Leu & 0.143 & UUA & UUG & 0.300 & 0.233 \\
\hline 4066 & Asn & 0.143 & AAC & AAU & 0.307 & 0.693 \\
\hline 4156 & Lys & 0.143 & AAG & AAA & 0.381 & 0.619 \\
\hline \multicolumn{7}{|l|}{ 3' noncoding } \\
\hline 4395 & $3^{\prime} \mathrm{NC}$ & 0.143 & G & A & - & - \\
\hline 4430 & $3^{\prime} \mathrm{NC}$ & 0.143 & C & U & - & - \\
\hline 4482 & $3^{\prime} \mathrm{NC}$ & 0.143 & G & $A$ & - & - \\
\hline \multicolumn{7}{|l|}{ L segment } \\
\hline 817 & Ser & 0.300 & UCA & UCG & 0.269 & 0.048 \\
\hline \multicolumn{7}{|l|}{ 3' noncoding } \\
\hline 6888 & $3^{\prime} \mathrm{NC}$ & 0.300 & $\mathrm{U}$ & $\mathrm{C}$ & - & - \\
\hline Average & & & & & 0.317 & 0.362 \\
\hline $\begin{array}{l}\text { T-test [ } 25 \text { d.f. }] \\
\text { prob. }\end{array}$ & & & & & 0.130 & \\
\hline
\end{tabular}


of these genotypes and instead they would be manifested as a large frequency of singleton $\eta_{\mathrm{e}}$ alleles. This trend was especially pronounced in the $\mathrm{M}$ segment in general and in the NSm gene in $\mathrm{SI}+$ isolates in particular. There was $>9$ fold nucleotide diversity in the NSm gene among SI+ isolates as compared with I+ isolates (Table 4). Despite having 37 segregating sites, none of these were singletons in $\mathrm{SI}+$ while four of only five sites were singletons in $\mathrm{I}+$ individuals. This suggests that disruptive selection was increasing the frequency of shared $\left(\eta_{i}\right)$ genotypes in SI+ mosquitoes while no such selection favored any of the I+ genotypes resulting in singletons $\left(\eta_{\mathrm{e}}\right)$ in those mosquitoes. Overall, LACV NSm sequences in SI+ mosquitoes differed between sites, suggesting that different polymorphisms in NSm may condition the SI+ phenotype. These polymorphisms would be expected in a quasispecies model of LACV infection in mosquitoes, and different polymorphisms in NSm and Ae. triseriatus innate immune genes could condition the same SI+ phenotype in different sites or geographic islands in the endemic area.

In one site (NAT), we were able to characterize NSs and NSm gene sequences from $\mathrm{SI}+$ and $\mathrm{I}+$ mosquitoes (Figure 9). There were no differences in NT sequence in the NSs genes (Additional File - Figure 1), but there were multiple NT and four amino acid differences between LACV NSm gene from SI+ and I+ mosquitoes in the site (Figure 9). The role that these changes may have in conditioning the establishment of the respective phenotypes remains to be determined. Sequence analysis of the Ae. triseriatus inhibitor of apoptosis-1 (AtIAP1) gene in mosquitoes from our study area revealed extensive polymorphisms (approximately 3 fold greater diversity than in a typical mosquito gene). One would assume that this gene would be highly conserved to prevent apoptosis [43].

In the D. melanogaster-SIGMAV system, the ref(2)P gene, which determines stabilized virus infection of the host, is also highly variable, presumably as a result of the host counteracting genetic changes in the virus [44]. The fly $\operatorname{ref}(2) P$ locus has two principal alleles, $\operatorname{ref}(2) P^{\mathrm{P}}$ and $\operatorname{ref}(2) \mathrm{P}^{\mathrm{O}}$, respectively, which determine whether or not the fly will restrict Sigma virus infection or be permissive to stabilized infection [45]. There is a well characterized innate immune arms race between the ref(2)p gene and SIGMAV N protein epitopes [40], which determines productive infection of the host, TOT of the virus, and stabilized infection. The gene product of the $\operatorname{ref}(2) P$ locus is a protein kinase in the Toll innate immune pathway [46]. Perhaps a similar major innate immune gene-for-gene interaction conditions the LACV SI+ and I+ phenotypes in Ae. triseriatus. The accumulating evidence suggests that interactions between the LACV NSm and the AtIAP1 gene may somehow condition the SI+ phenotype.
In this regard, apoptosis and autophagy have been show to share common caspase regulatory pathway components, autophagy and apoptosis both occur during degeneration of ovarian follicles, and autophagy has just been recognized as a key antiviral response in $D$. melanogaster [23-26]. All of this is especially provocative in the context of the LACV-Ae. triseriatus system in which virus amplification and maintenance in nature is predicated upon productive infection of ovarian follicles. Infection of $A e$. triseriatus ovarian follicles with West Nile virus, but not LACV, induces an autophagosomic response in the follicles (BJB, unpublished data). Reverse genetics capability is now available for $\mathrm{LACV}$, and we can exploit this robust approach to investigate and identify potential viral determinants of the SI+ and I+ phenotypes [47].

Mating efficiency studies with the newly discovered SI+ and I+ mosquitoes are also needed. Previous studies demonstrated a fitness advantage with increased mating efficiency for LACV-infected mosquitoes from the field, but the mosquitoes were not phenotyped in terms of SI+ or I+ infection [48]. The mating advantage may be more pronounced in SI+ mosquitoes. Mathematical models of LACV and KEYV [13-15] need to consider such factors as stabilized infection or mating advantages resulting from such infection. These two factors may help maintain stable LACV prevalence from year to year in the vector population.

\section{Conclusions}

Processing of individual adult Ae. triseriatus mosquitoes emerged from field collected eggs revealed the presence $\mathrm{SI}+$ and I+ mosquitoes in nature. SI+ mosquitoes could represent stabilized infections. Such mosquitoes could be present in low numbers, but could nonetheless maintain the virus in an area. Understanding the molecular basis of the SI+ phenotype would provide biomarkers for improved risk assessment and for targeting control programs for LACV encephalitis and other arboviral diseases.

\section{Methods \\ Egg collection}

Aedes triseriatus eggs were collected by the La Crosse County Public Health Department from five oviposition traps in each of 119 sites in Minnesota $(n=30)$, Wiscon$\sin (n=83)$ and Iowa $(n=6)$ (Figure 1$)$. Mosquito eggs were collected between mid-June and October of 2006 and 2007 in Crawford (2006: 8 sites, 2007: 15 sites), La Crosse (2006: 6 sites, 2007: 37 sites), Monroe (2006: 3 sites, 2007: 12 sites), Vernon (2006: 11 sites, 2007: 12 sites), Lafayette (2006 and 2007: 2 sites), and Iowa (2006: 2 sites, 2007: 4 sites) counties in Wisconsin, Winona (2006: 7 sites, 2007: 13 sites) and Houston (2006: 10 sites, 2007: 17 sites) counties in Minnesota and Clayton county 


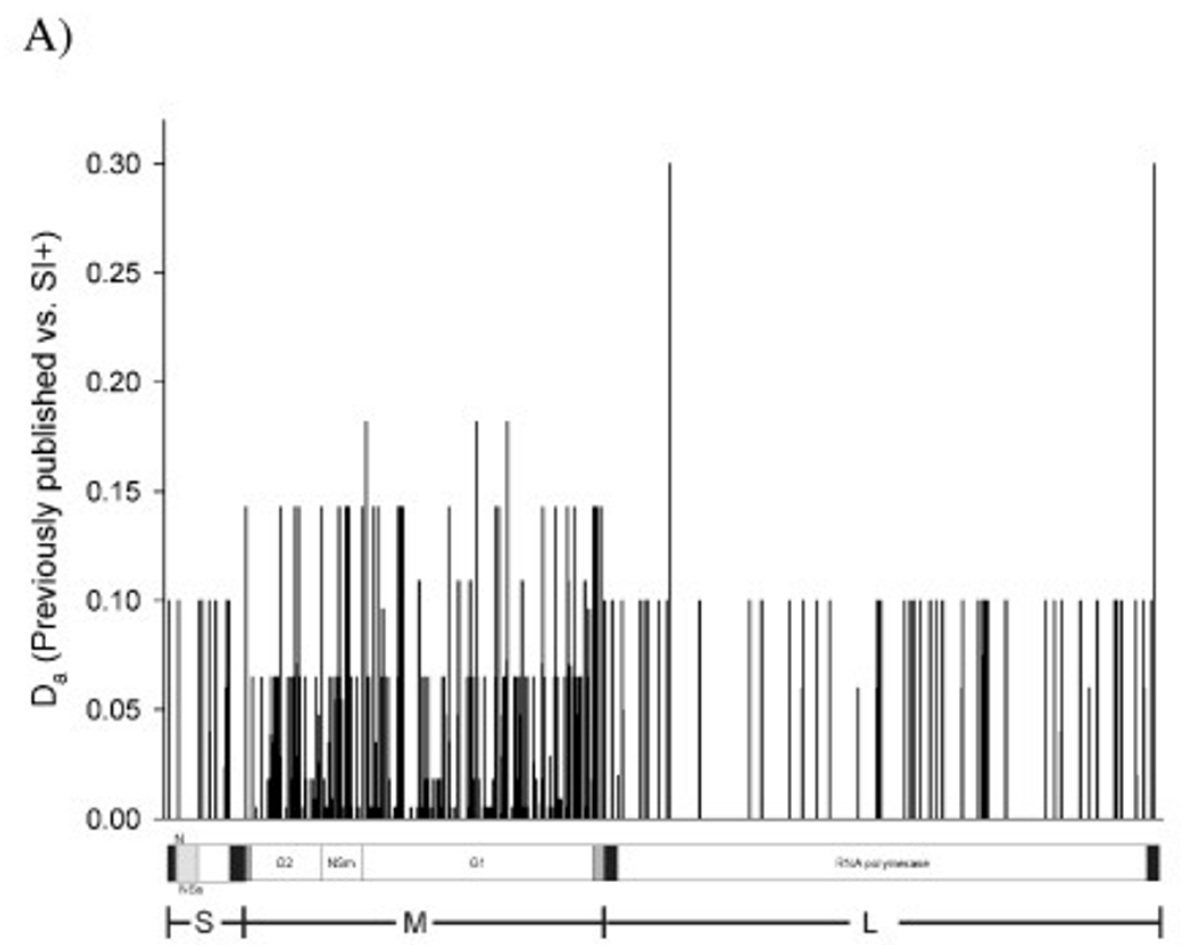

B)

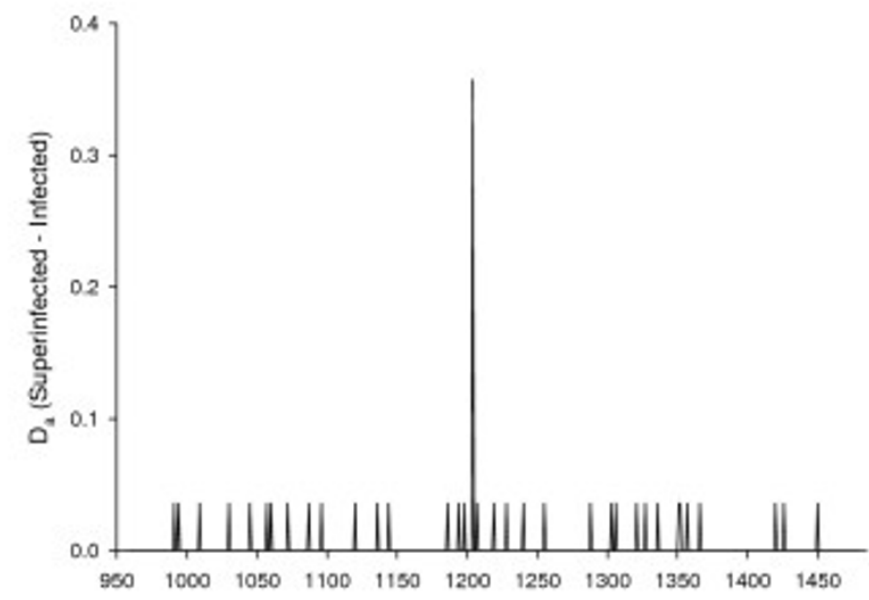

Figure 8 Nucleotide differences $\left(D_{a}\right)$ between RNA segments from LACV SI+ and previously published isolates (a) and between NSM sequences from $\mathrm{SI}+$ and $\mathrm{I}+$ mosquitoes (b)

(2007: 6 sites) in Iowa. The eggs were transported to the insectaries at the Arthropod-borne and Infectious Diseases Laboratory (AIDL) at Colorado State University (CSU), Fort Collins, $\mathrm{CO}$ and maintained in the insectary until hatching and processing.

\section{Immunofluorescence assay}

Approximately 2 - 4 days post-emergence, a mosquito leg was removed, squashed onto an acid-washed microscope slide, and fixed in cold acetone. Legs were then assayed for LACV antigen by direct immunofluorescence assay (IFA) [5]. Variation in the amount of LACV antigen was evident among these mosquitoes. The degree of fluorescence was assigned quantitative scores to provide more information about the nature of the infection in the respective mosquitoes. An IFA score of 0 indicated no detectable antigen; 1 - small amounts of antigen in some tissues; 2 - small amounts of antigen in most tissues, 3 - 
I+LAC05/KBT/Monroe, WI /m/07A I+LAC0 6/GOLF/Houston, MN/m/07A $\mathrm{I}+\mathrm{LAC} 07 / \mathrm{HIDV} / \mathrm{Wi}$ nona, MN/m/07A $\mathrm{I}+\mathrm{LAC} 09 / \mathrm{HIDV} / \mathrm{Wi}$ nona, MN/m/07B $\mathrm{I}+\mathrm{LAC} 12 / \mathrm{LCVP} /$ Houston, $\mathrm{MN} / \mathrm{m} / 07 \mathrm{~A}$ I+LAC13/ALP/LaCrosse, WI/m/0 7A $\mathrm{I}+\mathrm{LAC} 14 / \mathrm{DAKE} / \mathrm{Wi}$ nona, $\mathrm{MN} / \mathrm{m} / 07 \mathrm{~A}$ $\mathrm{I}+\mathrm{LAC} 27 / \mathrm{CAL}-\mathrm{GA} /$ Houston, $\mathrm{MN} / \mathrm{m}$ $\mathrm{I}+\mathrm{LAC} 28 / \mathrm{CAL}-\mathrm{GA} /$ Houston, $\mathrm{MN} / \mathrm{m}$ I+LAC29/CAL-GA/Houston, MN/m $\mathrm{I}+\mathrm{LAC} 08 / \mathrm{NAT} /$ Crawford, WI/m/07B $\mathrm{I}+\mathrm{LAC10} / \mathrm{NAT} / \mathrm{Crawford}, \mathrm{WI} / \mathrm{m} / 07 \mathrm{C}$ $\mathrm{SI}+\mathrm{LAC} 03 / \mathrm{NAT} /$ Crawford, WI/m/07A SI+LAC16/NAT/Crawford, WI/m/07B SI+LAC19/BEN2/Lafayette, WI/m/07D SI+LAC20/BEN2/Lafayette, WI/m/07E SI+LAC21/BEN2/Lafayette, WI/m/07F $\mathrm{SI}+\mathrm{LAC} 22$ / CAL-GA/Houst on, $\mathrm{MN} / \mathrm{m} / 07 \mathrm{G}$ $\mathrm{SI}+\mathrm{LAC} 23$ / CAL-GA/Houston, MN/m/07J $\mathrm{SI}+\mathrm{LAC} 24$ / CAL-GA/Houst on, MN/m/07K

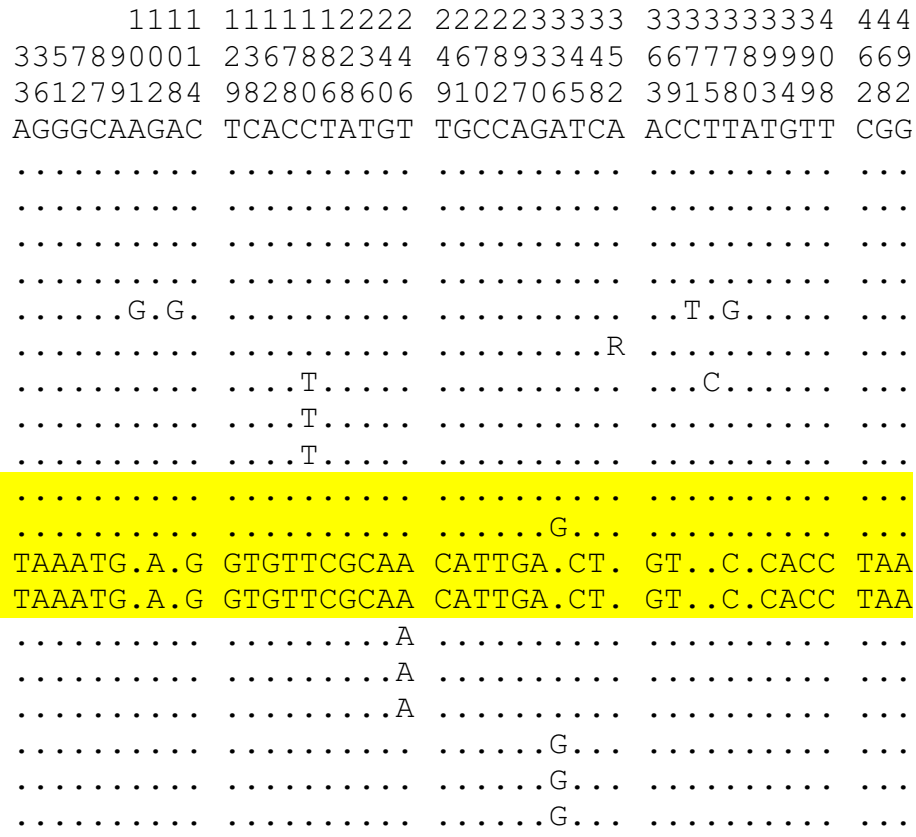

b

Position

3467223

4309472

\# I+LAC05/KBT/Monroe, WI/m/07A

EDLITQA

\# I+LAC0 $6 / \mathrm{GOLF} /$ Houston, MN/m/07A

\#I+LAC0 7/HDV/Winona, MN/m/07A

$\ldots \ldots$

$\ldots \ldots$

$\ldots \ldots$

$\ldots \ldots \ldots$

G...IR.

I + LAC12/LCVP/Houston, MN/m/07A

\# I+LAC13/ALP/LaCrosse, WI/m/07A

\#I+LAC14/DAKE/Winona, MN/m/0 7A

\# I+LAC2 7 / CAL-GA/Houston, MN/m

\# I+LAC2 $8 / \mathrm{CAL}-\mathrm{GA} /$ Houston, MN $/ \mathrm{m}$

\# I+LAC2 9/CAL-GA/Houston, MN/m

\# I+LAC0 8/NAT/Crawford,WI/m/07B

\# I+LAC10/NAT/Crawford, WI/m/07C

\#SI+LAC03/NAT/Crawford,WI/m/07A

\#SI+LAC16/NAT/Crawford,WI/m/07B

\#SI+LAC19/BEN2/Lafayette,WI /m/07D

\#SI+LAC20/BEN2/Lafayette, WI/m/07E

\#SI+LAC21/BEN2/Lafayette, WI /m/07F

\#SI +LAC22/CAL-GA/Houston, MN/m/07G

\#SI+LAC23/CAL-GA/Houston, MN $/ \mathrm{m} / 07 \mathrm{~J}$

\#SI+LAC2 4/CAL-GA/Hous ton, MN/m/07K

$\ldots \ldots$

$\ldots \ldots$

$\ldots \ldots$

$\ldots \ldots$

$\ldots \ldots$

$\ldots \ldots$

.EFT..T

EFT. . T

.....

$\ldots \ldots$

$\ldots \ldots$

$\ldots \ldots$

$\ldots \ldots$

$\ldots \ldots$

Figure 9 LACV NSm NT (a) and AA (b) differences between SI+ and I+ mosquitoes from one site. Sequences from the NAT site are highlighted in yellow.

significant amounts of antigen in some tissues, 4 - significant amounts of antigen in most tissues, and 5 - major accumulations of viral antigen in the leg tissues (Figure 2). Mosquitoes that received an IFA score of 5 were desig- nated as super-infected (SI+), mosquitoes with IFA scores of 1-4 were designated as infected (I+), and mosquitoes with an IFA score of zero were designated as LACV negative (I-) (Figure 2). 


\section{Virus isolation}

SI+ and I+ mosquitoes, as identified by IFA, were triturated with a pellet pestle (Fisher Scientific, Pittsburgh, $\mathrm{PA}$ ) in a $1.5 \mathrm{ml}$ microcentrifuge tube containing $1 \mathrm{ml}$ of minimal essential medium (MEM) (Invitrogen, Carlsbad, CA), $2 \%$ fetal bovine serum, $200 \mu \mathrm{g} / \mathrm{ml}$ penicillin/streptomycin, $200 \mu \mathrm{g} / \mathrm{ml}$ fungicide, $7.1 \mathrm{mM}$ sodium bicarbonate, and $1 \times$ nonessential amino acids. The homogenate was centrifuged for 10 minutes at $500 \times \mathrm{g}$ to form a pellet.

Monolayers of Vero E6 cells were grown in six-well plates at $37^{\circ} \mathrm{C}$ in an atmosphere of $5 \% \mathrm{CO}_{2}$. Supernatant from each centrifuged mosquito homogenate $(200 \mu \mathrm{l})$ was added to one well of a six-well plate and incubated at $37^{\circ} \mathrm{C}$ for one hour. Following incubation, $5 \mathrm{ml}$ of medium were added to each well. The isolation of LACV was revealed by the presence of cytopathic effects (CPE) five days post-infection [33].

\section{Titrations}

The LACV titers of SI+ mosquitoes were determined by endpoint titration in Vero E6 cells [33]. The mosquito homogenates were serially diluted $10^{-1}-10^{-6}$ and $200 \mu \mathrm{l}$ of each dilution was added to one well of a 96 well plate. Five days post-infection, the endpoint was determined as the highest dilution causing CPE. The virus titer was calculated and expressed as $\log _{10} \mathrm{TCID}_{50} / \mathrm{ml}$ [49].

\section{Plaque purification}

Monolayers of Vero E6 cells in six-well plates were used for plaque purification of LACV isolates [33]. Virus isolates were serially diluted $10^{-1}$ to $10^{-6}$ and $200 \mu \mathrm{l}$ of each virus dilution was added to one well and incubated at $37^{\circ} \mathrm{C}$ for 1 hour. The virus inoculum was then removed and $5 \mathrm{ml}$ of overlay (1\% agar in Medium 199, 10\% fetal bovine serum, $7.1 \mathrm{mM}$ sodium bicarbonate, $0.2 \%$ diethylaminoethyl-dextran in Hank's BSS, 1× Eagle basal medium vitamins, $1 \times$ Eagle basal amino acids) were added to the well. After six days of incubation at $37^{\circ} \mathrm{C}$ in $5 \% \mathrm{CO}_{2}, 200 \mu \mathrm{l}$ of the detection solution, methylthiazolyldiphenyl-tetrazolium bromide (MTT, $5 \mathrm{mg} / \mathrm{ml}$ in PBS), were added to each well. The plates were incubated overnight and wells were then examined for plaques. Isolated plaques were individually picked and placed in $1 \mathrm{ml}$ of MEM with $0.2 \% \mathrm{FBS}$ for $1 \mathrm{~h}$ at $37^{\circ} \mathrm{C}$. The eluted virus was added to a Vero cell monolayer in one well of a six-well plate. The cells were then incubated for five to seven days and the presence of virus was confirmed by CPE.

\section{RNA purification from virus isolates and amplification by reverse transcription PCR}

Supernatant and cells from the wells containing plaque purified virus were removed and placed in a $15 \mathrm{ml}$ conical tube and centrifuged at $3000 \mathrm{rpm}$ for 10 minutes. The supernatant was removed, the cell pellet was resuspended in $500 \mu \mathrm{l}$ of TRIzol, and total RNA was extracted according to manufacturer's instructions (Invitrogen, Carlsbad, CA). The entire $S, M$, and L RNA segments were transcribed to cDNA using Superscript II reverse transcriptase (Invitrogen, Carlsbad, CA) and amplified by PCR using Ex Taq DNA polymerase (Takara, Shiga, Japan) according to manufacturer's instructions. The $\mathrm{S}$ segment was amplified in two separate fragments, the $M$ segment in three fragments, and the L segment in four fragments (Table 6). PCR was performed in a thermal cycler with the following program: $94^{\circ} \mathrm{C}$ for $5 \mathrm{~min}, 37$ cycles of $\left[94^{\circ} \mathrm{C}\right.$ for $1 \mathrm{~min}$., $57^{\circ} \mathrm{C}$ for $1 \mathrm{~min}$. and $72^{\circ} \mathrm{C}$ for 2.5 min] followed by a final extension at $72^{\circ} \mathrm{C}$ for $8 \mathrm{~min}$.

\section{Sequencing}

PCR products were separated by electrophoresis in $1 \%$ agarose gels with Tris-acetate-EDTA (TAE) buffer, stained with ethidium bromide, excised and extracted using the Powerprep Express Gel Extraction kit (Marligen Biosciences, Ijamsville, MD) according to manufacturer's instructions. PCR products were sequenced using the ABI PRISM dye terminator cycle sequencing kit (Applied BioSystems, Foster City, CA) and the ABI 310 DNA automated sequencer at Macromolecular Resources, CSU.

\section{Amplification of NSs and NSm genes of LACVs from $\mathrm{SI}+$ and I+ mosquitoes}

I+ and SI+ mosquitoes were triturated in $500 \mu \mathrm{l}$ TRIzol LS reagent (Invitrogen, Carlsbad, CA), and total RNA was isolated from the homogenate per manufacturer's instructions. NSs and NSm genes were transcribed and PCR amplified in separate reactions using SuperScript ${ }^{\mathrm{TM}}$ III One-Step RT-PCR Kit with Platinum ${ }^{\circ}$ Taq (Invitrogen, Carlsbad, CA). External primers are listed in Table 6. The thermal cycling conditions for the RT-PCR protocol were: $55^{\circ} \mathrm{C}$ for $30 \mathrm{~min}, 94^{\circ} \mathrm{C}$ for $2 \mathrm{~min}, 40$ cycles of $\left[94^{\circ} \mathrm{C}\right.$ for $30 \mathrm{~s}, 56^{\circ} \mathrm{C}$ for $30 \mathrm{~s}$, and $68^{\circ} \mathrm{C}$ for $1 \mathrm{~min}$ ] followed by a final extension at $68^{\circ} \mathrm{C}$ for $5 \mathrm{~min}$. RT-PCR products were further amplified by nested PCR using Vent DNA polymerase (New England Biolabs, Ipswich, MA). Internal primers are listed in Table 6 . The thermal cycling conditions were: $94^{\circ} \mathrm{C}$ for $2 \mathrm{~min}, 35$ cycles of $\left[94^{\circ} \mathrm{C}\right.$ for $30 \mathrm{~s}$, $56^{\circ} \mathrm{C}$ for $30 \mathrm{~s}$, and $72^{\circ} \mathrm{C}$ for $75 \mathrm{~s}$ ] followed by a final extension at $72^{\circ} \mathrm{C}$ for $5 \mathrm{~min}$.

For virus isolates obtained from SI+ mosquitoes, $200 \mu \mathrm{l}$ virus stock were added to $600 \mu \mathrm{l}$ TRIzol LS reagent and viral RNA was isolated per manufacturer's instructions. NSs and NSm were transcribed and PCR amplified in separate reactions. Primers used in these reactions were the same as those used for the nested PCR step of I+ and SI+ samples. A nested PCR step was unnecessary and not applied to SI+ isolates. PCR amplicons were purified with QIAquick PCR Purification Kit (Qiagen, Valencia, CA) and sequenced bi-directionally as above. Sequences were 
Table 6: Primer sets for amplification of the LACV RNA

\begin{tabular}{|c|c|c|c|c|}
\hline Genome Segment & Primer & Primer Sequence (5'-3') & Primer position & Product Size (bp) \\
\hline \multicolumn{5}{|c|}{ Primers used for the amplification of genome segments } \\
\hline \multirow[t]{2}{*}{ S-A } & SF1 & AGTAGTGTACCCCACTTGAATAC & $1-23$ & 525 \\
\hline & SR & CTTAAGGCCTTCTTCAGGTATTGAG & $549-572$ & \\
\hline \multirow[t]{2}{*}{ S-B } & SF3 & CTTAAGGCCTTCTTCAGGTATTGAG & $453-476$ & 486 \\
\hline & SR1 & AGTAGTGTGCCCCACTGAATAC & $963-984$ & \\
\hline \multirow[t]{2}{*}{$\mathrm{M}-\mathrm{C}$} & MF1 & AGTAGTGTACTACCAAGTATAGATGAACG & $1-27$ & 2211 \\
\hline & MR10 & GACTCCTITCCTCTAGCAAGG & $2239-2258$ & \\
\hline \multirow[t]{2}{*}{ M-D } & MF9 & CAGACAACATGGAGAGTGTAC & $1798-1818$ & 1786 \\
\hline & MR5 & GTCAAATCTGGGAACTCCATTGCC & $3605-3628$ & \\
\hline \multirow[t]{2}{*}{$M-E$} & MF15 & CAAGCTCATGGGGATGCGAAGAG & $3249-3271$ & 1235 \\
\hline & MR1 & AGTAGTGTGCTACCAAGTATA & $4507-4527$ & \\
\hline \multirow[t]{2}{*}{ L-F } & LF1 & AGTAGTGTACCCCTATCTACAAAAC & $1-25$ & 2955 \\
\hline & LR20 & GTITCCCTCTGTTCGCACTC & $2381-2401$ & \\
\hline \multirow[t]{2}{*}{ L-G } & LF8A & CAACTTGCCTACTATTCAAAC & 1899-1919 & 2164 \\
\hline & LR7 & CCAATCCAACTGTACTAATCATTGAC & $4084-4108$ & \\
\hline \multirow[t]{2}{*}{ L-H } & LF8 & GCTACCAGGGCAGTCAAATGACCC & $3987-4011$ & 1949 \\
\hline & LR10 & СCTCTGCAACGTTAACTACACATACTG & $5961-5986$ & \\
\hline \multirow[t]{2}{*}{ L-I } & LF10 & CAGATATTGTCTGGTGGCCATAAAGCC & $5288-5314$ & 1646 \\
\hline & LR12 & AGTAGTGTGCCCCTATCTTC & $6961-6980$ & \\
\hline \multicolumn{5}{|c|}{ Primers used for the amplification of NSs and NSm } \\
\hline \multirow[t]{2}{*}{$\mathrm{S}$} & NSsF-int & TTTGAAAATAAATTGTTGTTGACTG & $24-48$ & 472 \\
\hline & NSsR-int & CCCACTGTCCCATCCTACAC & $476-495$ & \\
\hline \multirow[t]{2}{*}{$\mathrm{S}$} & NSsF-ext & ACTCCACTTGAATACTTTGAAAATAAA & $9-35$ & 563 \\
\hline & NSsR-ext & CAATGGTCAGCGGGTAGAAT & $552-571$ & \\
\hline \multirow[t]{2}{*}{ M } & NSmF-int & CTGGATTGTGCCCTGGTTAT & $918-937$ & 598 \\
\hline & NSmR-int & TCAGTCTCTAGGCAGGTGGTG & $1495-1515$ & \\
\hline \multirow[t]{2}{*}{ M } & NSmF-ext & GCGGTGCTCGCTATGATACT & $870-889$ & 742 \\
\hline & NSmR-ext & AATTGGGTTGCAATGTTGGT & $1592-1611$ & \\
\hline
\end{tabular}


assembled and aligned using ContigExpress and AlignX software (Invitrogen, Carlsbad, CA).

\section{Phylogenetic analyses}

LACV was isolated from five SI+ mosquitoes and RNA was extracted from the isolates, amplified by RT-PCR, and sequenced. The entire $\mathrm{S}, \mathrm{M}$ and $\mathrm{L}$ segments were sequenced and analyzed. Previously published LACV sequences [50-54] were obtained from GenBank. The viruses used in this analysis and their respective GenBank Accession numbers are listed in Table 3.

Maximum Likelihood (ML) trees [55] were derived for all three segments and for the NSm dataset using RAxML (Randomized Axelerated Maximum Likelihood) [56,57]. RAxML performs sequential and parallel ML based inference of large phylogenetic trees. RAxML was initially used to generate five fixed starting Maximum Parsimony (MP) trees and these were then used as starting trees to estimate ML trees using a fixed setting with GTRMIX and then using the automatically determined setting on the same five starting MP trees. We evaluated the final trees under GTRGAMMA to compare the final likelihoods. The conditions that yielded the best likelihood scores were used in further analyses. Next the optimal number of parameters in the ML models was determined by increasing the number of parameters by increments of 5 up to 55. Again GTRGAMMA was used to compare the final likelihoods. GTRMIX located the Best-Known Likelihood (BKL) tree and GTRCAT performed bootstrapping with 100 pseudo-replications. This generated a bipartitions Newick treefile with information on ML topology, rates and bootstrap support. This bipartitions Newick file was loaded into TreeGraph2 http://treegraph.bioinfweb.info/ to produce the final phylogeny graphics.

\section{Analyses of molecular evolution}

DNAsp5.0 [58] was used to assign coding and noncoding regions in the $\mathrm{S}, \mathrm{M}$ and $\mathrm{L}$ segments and to subdivide each sequence dataset into previously published versus SI+ groups. DNAsp5.0 then computed in each group the number of segregating sites $(\mathrm{S})$, unique haplotypes (Hap), and singletons $\eta_{\mathrm{e}}$. Nucleotide diversity $(\pi-\mathrm{Nei}[36]), \pi_{\mathrm{s}}$ among synonymous sites, $\pi_{\mathrm{a}}$ among replacement sites, $\theta$ / comp [36], and $F^{*}$ [59] were also computed with DNAsp5.0.

$\mathrm{F}^{*}$ is a normalized comparison of shared substitutions $\left(\eta_{\mathrm{i}}\right)$ relative to those appearing once, "singletons" $\left(\eta_{\mathrm{e}}\right)$. While no explicit examination of a genealogy is involved, the $\mathrm{F}^{*}$ test assumes that singletons arose recently and appear on the tips of branches while shared mutations $\left(\eta_{\mathrm{i}}\right)$ are older and arose internally on nodes of the genealogy. When alleles are maintained at frequencies that approximate the average mutation rate then $\mathrm{F}^{*}=0$ and polymorphisms are assumed to evolve in a manner predicted by neutral evolution. Fu and $\mathrm{Li}$ [59] pointed out that $\mathrm{F}^{*}=0$ does not imply no selection because the neutral model implicitly assumes that the majority of novel alleles are deleterious and removed through purifying selection. In contrast, $\mathrm{F}^{*}<0$ values reflect an excess of singletons $\left(\eta_{\mathrm{e}}\right)$ in a population and this pattern is consistent with positive selection wherein genetic variants sweep throughout a population. Conversely, $\mathrm{F}^{*}>0$ values indicate an excess of intermediate-frequency $\eta_{i}$ alleles and can result from balancing selection or disruptive selection maintaining alleles at frequencies greater than the average mutation rate. DNAsp5.0 was also used to compute confidence intervals of $\mathrm{F}^{*}$ by simulations using the coalescent algorithm and to compute differences in nucleotide frequency $\left(D_{a}\right.$ - Nei [36]) between previously published and SI+ isolates across the LACV genome and gene sequences using the Sliding Window method.

Relative Synonymous Codon Usage (RSCU) was analyzed within and among previously published and SI+ isolates using the GCUA (General Codon Usage Analysis) package [35]. The program was subsequently used to perform three analyses on the codon usage tables: 1) correspondence analysis (CA) [60]), 2) Principal Components Analysis (PCA) and 3) a cluster analysis based upon McInerney's distance measure [35], based on the differences in RSCU values.

\section{Additional material}

Additional file 1 Figure 1. Nucleotide sequence of LACV NSs from SI+ and I+ mosquitoes from one site. The NT sequence is absolutely conserved in all NSs genes analyzed.

\section{Competing interests}

The authors declare that they have no competing interests.

\section{Authors' contributions}

SMR conducted mosquito rearing from field collected liners, mosquito IFA, $P C R$, and virus isolation assays, and phylogenetic analyses. ECM conducted LACV NSs and NSm amplifications from SI+ and I+ mosquitoes and analyzed NT and AA variability in the respective phenotypes. MKB participated in mosquito rearing and IFA phenotyping of mosquitoes and in manuscript preparation and submission. ETB first detected SI+ mosquitoes and participated in early studies to characterize the phenotypes. DG supervised all field crews for identifying field sites, collecting of Ae. triseriatus eggs and processing and shipping of oviposition liners to Colorado. CDB and BJB were CO-PIs of the $\mathrm{NIH}$ grant that made these studies possible, established the overall studies and experimental design, supervised laboratory and virologic investigations, analyzed data, and prepared the manuscript. WCB over saw and conducted molecular evolution and phylogenetic analyses and prepared the manuscript. All authors participated in the preparation of this manuscript and approve its submission to Virology Journal.

\section{Acknowledgements}

This research was funded by grant Al 32543 from the National Institutes of Health. SR was supported by CDC FTP T01/CCT 822307. We thank Charles Calisher for helpful comments during the preparation of the manuscript and for virus isolation studies. We thank the staff of the La Crosse County Health Department's vector control section for collecting the field samples used in these studies. 


\section{Author Details}

${ }^{1}$ Arthropod-Borne and Infectious Diseases Laboratory, Department of Microbiology, Immunology and Pathology, Colorado State University, Fort Collins, Colorado 80523-1692, USA, ${ }^{2}$ Current address: Colorado Department of Public Health and Environment, 4300 Cherry Creek Drive South, Denver, CO 80246, USA, ${ }^{3}$ Current address: Midwest Respiratory Virus Program, Department of Pediatric Infectious Diseases, Medical College of Wisconsin, Milwaukee, WI 53226, USA and 4 La Crosse County Health Department, La Crosse, WI 546013228 , USA

\section{Received: 4 February 2010 Accepted: 22 April 2010}

Published: 22 April 2010

\section{References}

1. Rust RS, Thompson WH, Matthews CG, Beaty BJ, Chun RMW: La Crosse and other forms of California encephalitis. Journal of Child Neurology 1999, 14:1-14.

2. Reimann CA, Hayes EB, DiGuiseppi C, Hoffman R, Lehman JA, Lindsey NP, Campbell GL, Fischer M: Epidemiology of neuroinvasive arboviral disease in the United States, 1999-2007. American Journal of Tropical Medicine and Hygiene 2008, 79:974-979.

3. Pantuwatana S, Thompson WH, Watts DM, Yuill TM, Hanson RP: Isolation of La Crosse virus from field collected Aedes triseriatus larvae. American Journal of Tropical Medicine and Hygiene 1974, 23:246-250.

4. Watts DM, Thompson WH, Yuill TM, DeFoliart GR, Hanson RP: Overwintering of La Crosse virus in Aedes triseriatus. American Journal of Tropical Medicine and Hygiene 1974, 23:694-700

5. Beaty BJ, Thompson WH: Emergence of La Crosse virus from endemic foci. American Journal of Tropical Medicine and Hygiene 1975, 24:685-690

6. Miller BR, DeFoliart GR, Yuill TM: Vertical transmission of La Crosse virus (California encephalitis group): Transovarial and filial infection rates in Aedes triseriatus. Journal of Medical Entomology 1977, 14:437-440.

7. Lisitza MA, DeFoliart GR, Yuill TM, Karandinos MG: Prevalence rates of La Crosse virus (California encephalitis group) in larvae from overwintered eggs of Aedes triseriatus. Mosquito News 1977, 37:745-750.

8. McGaw MM, Chandler LJ, Wasieloski LP, Blair CD, Beaty BJ: Effect of La Crosse virus infection on overwintering of Aedes triseriatus. American Journal of Tropical Medicine and Hygiene 1998, 58:168-175.

9. Keene KM, Foy BD, Sanchez-Vargas I, Beaty BJ, Blair CD, Olson KE: RNA interference acts as a natural antiviral response to O'nyong-nyong virus (Alphavirus; Togaviridae) infection of Anopheles gambiae. Proceedings of the National Academy of Sciences of the United States of America 2004, 101:17240-17245.

10. Campbell CL, Black WC, Hess AM, Foy BD: Comparative genomics of small RNA regulatory pathway components in vector mosquitoes. BMC Genomics 2008, 9:425-441.

11. Xi ZY, Ramirez JL, Dimopoulos G: The Aedes aegypti Toll pathway controls dengue virus infection. Plos Pathogens 2008, 4:

12. Sánchez-Vargas I, Scott JC, Poole-Smith BK, Franz AW, Barbosa-Solomieu V, Wilusz J, Olson KE, Blair CD: Dengue virus type 2 infections of Aedes aegypti are modulated by the mosquito's RNA interference pathway. PLOS Pathog 2009:5L e1000299.

13. Defoliart GR: Aedes triseriatus: Vector biology in relationship to the persistence of La Crosse virus in endemic foci. California Serogroup Viruses 1983:89-104

14. Fine PEM, LeDuc JW: Towards a quantitative understanding of the epidemiology of Keystone virus in the Eastern United States. American Journal of Tropical Medicine and Hygiene 1978, 27:322-338.

15. Fine PEM: Vectors and vertical transmission: an epidemiologic perspective. Annals New York Academy of Sciences 1975, 266:173-194.

16. Seecof R: The Sigma virus infection of Drosophila melanogaster. Current Topics in Microbiology and Immunology 1968, 42:59-93.

17. Fleuriet A: Maintenance of a hereditary virus - the Sigma virus in populations of its host, Drosophila melanogaster. Evolutionary Biology 1988, 23:1-30

18. Tesh R, Shroyer DA: The mechanism of arbovirus transovarial transmission in mosquitoes: San Angelo virus in Aedes albopictus. American Journal of Tropical Medicine and Hygiene 1980, 29:1394-1404.

19. Turell MJ, Hardy JL, Reeves WC: Stabilized infection of California encephalitis virus in Aedes dorsalis. American Journal of Tropical Medicine and Hygiene 1982, 31:1252-1259.
20. Beck ET: Analyzing the role of the Aedes triseratus inhibitor of apoptosis 1 gene in transovarial transmission of La Crosse virus. In PhD thesis Colorado State University, Microbiology, Immunology, and Pathology Department; 2007.

21. Franz AWE, Sanchez-Vargas I, Adelman ZN, Blair CD, Beaty BJ, James AA, Olson KE: Engineering RNA interference-based resistance to dengue virus type 2 in genetically modified Aedes aegypti. Proceedings of the National Academy of Sciences of the United States of America 2006, 103:4198-4203.

22. Girard YA, Schneider BS, McGee CE, Wen J, Han VC, Popov V, Mason PW, Higgs S: Salivary gland morphology and virus transmission during long-term cytopathologic West Nile virus infection in Culex mosquitoes. American Journal of Tropical Medicine and Hygiene 2007, 76:118-128

23. Shelly S, Lukinova N, Bambina S, Berman A, Cherry S: Autophagy is an essential component of Drosophila immunity against vesicular stomatitis virus. Immunity 2009, 30:588-598

24. Cherry S: VSV infection is sensed by Drosophila, attenuates nutrient signaling, and thereby activates antiviral autophagy. Autophagy 2009 5:1067-1063.

25. Hou YC, Hannigan AM, Gorski SM: An executioner caspase regulates autophagy. Autophagy 2009, 5:530-533.

26. Hou YC, Chittaranjan S, Barbosa SG, McCall K, Gorski SM: Effector caspase Dcp-1 and IAP protein Bruce regulate starvation-induced autophagy during Drosophila melanogaster oogenesis. J Cell Biol 2008, 182:1127-1139.

27. Nezis IP, Stravopodis DJ, Margaritis LH, Papassideri IS: Autophagy is required for the degeneration of the ovarian follicular epithelium in the higher Diptera. Autophagy 2006, 2:297-298.

28. Lingel A, Simon B, Izaurralde E, Sattler M: The structure of the flock house virus B2 protein, a viral suppressor of RNA interference, shows a novel mode of double-stranded RNA recognition. EMBO Reports 2005, 6:1149-1155.

29. Bucher E, Sijen T, De Haan P, Goldbach R, Prins M: Negative-strand tospoviruses and tenuiviruses carry a gene for a suppressor of gene silencing at analogous genomic positions. J Virol 2003, 77:1329-36.

30. Soldan SS, Plassmeyer ML, Matukonis MK, Gonzalez-Scarano F: La Crosse virus nonstructural protein NSs counteracts the effects of short interfering RNA. Journal of Virology 2005, 79:234-244.

31. Won SY, Ikegami T, Peters CJ, Makino S: NSm protein of Rift Valley fever virus suppresses virus-induced apoptosis. Journal of Virology 2007, 81:13335-13345

32. Blakqori G, Delhaye S, Habjan M, Blair CD, Sanchez-Vargas I, Olson KE, Attarzadeh-Yazdi G, Fragkoudis R, Kohl A, Kalinke U, Weiss S, Michiels T, Staeheli P, Weber F: La Crosse bunyavirus nonstructural protein NSs serves to suppress the type I interferon system of mammalian hosts. Journal of Virology 2007, 81:4991-4999.

33. Beaty BJ, Calisher CH, Shope RE: Arboviruses. In Diagnostic procedures for viral, rickettsial, and chlamydial infections 6th edition. Edited by: Schmidt NJ, Emmons RW. Washington, D.C.: Am. Publ. Health Assoc; 1989:797-855.

34. Reese SM: Investigations of the evolutionary, epidemic and maintenance potential of La Crosse virus. In PhD thesis Colorado State University, Microbiology, Immunology, and Pathology Department; 2008.

35. McInerney JO: Replicational and transcriptional selection on codon usage in Borrelia burgdorferi. PNAS 1998, 95:10698-1703.

36. Nei M: Molecular Evolutionary Genetics. Colombia University Press. New York; 1987:512.

37. Bailey $C L$, Eldridge BF, Hayes DE, Watts DM, Tammariello RF, Dalrymple JM: Isolation of St. Louis encephalitis virus from overwintering Culex pipiens mosquitoes. Science 1978, 199:1346-1349.

38. Nasci RS, Savage HM, White DJ, Miller JR, Cropp BC, Godsey MS, Kerst AJ, Bennett P, Gottfried K, Lanciotti RS: West Nile virus in overwintering Culex mosquitoes, New York City, 2000. Emerging Infectious Diseases 2001, 7:742-744.

39. Fleuriet A: Transmission efficiency of the Sigma virus in natural populations of its host, Drosophila melanogaster. Archives of Virology 1982, 71:155-167.

40. Bangham J, Knott SA, Kang-Wook K, Young RS, Jiggins FM: Genetic variation affecting host-parasite interactions: major-effect quantitative trait loci affect the transmission of Sigma virus in Drosophila melanogaster. Molecular Ecology 2008, 17:3800-3807. 
41. Matthews TC, Craig GB Jr: Genetic heterozygosity in natural populations of the tree- hole mosquito Aedes triseriatus. Ann Entomol Soc Am 1980, 73:739-743.

42. Beck ET, Bosio CF, Geske DA, Blair CD, Beaty BJ, Black WC IV: An analysis of gene flow among Midwestern populations of the mosquito, Ochlerotatus triseriatus. American Journal of Tropical Medicine And Hygiene 2005, 73:534-540.

43. Beck ET, Fuentes SL, Geske DA, Blair CD, Beaty BJ, Black WC: Patterns of variation in the inhibitor of apoptosis 1 gene of Aedes triseriatus, a transovarial vector of La Crosse virus. Journal of Molecular Evolution 2009, 68:403-413.

44. Dru P, Bras F, Dezelee S, Gay P, Petitjean A, Peierre-Deneubourg A, Teninges D, Contamine D: Unusual variability of the Drosophila melanogaster ref(2)P protein which controls the multiplication of a Sigma Rhabdovirus. Genetics 1993, 133:943-954.

45. Contamine D, Petitjean A, Ashburner M: Genetic resistance to viral infection: the molecular cloning of a Drosphila gene that restricts infection by Rhabdovirus Sigma. Genetics 1989, 123:525-533.

46. Avila A, Silverman N, Diaz-Meco MT, Moscat J: The Drosophila atypical protein kinase C-Ref(2)P complex constitutes a conserved module for signaling in the Toll pathway. Molecular and Cellular Biology 2002, 22:8787-8795

47. Blakqori G, Weber F: Efficient cDNA-based rescue of La Crosse bunyaviruses expressing or lacking the nonstructural protein NSs. Journal of Virology 2005, 79:10420-10428.

48. Reese SM, Beaty MK, Gabitzsch ES, Blair CD, Beaty BJ: Aedes triseriatus females transovarially infected with La Crosse virus mate more efficiently than uninfected mosquitoes. J Med Entomol 2009, 46:1152-8.

49. Karber G: Beitrag zur kollektiven Behandlung pharmakologischer Reihenversuche. Arch Exp Pathol Parmakol 1931, 162:480-483.

50. Bennett RS, Ton DR, Hanson CT, Murphy BR, Whitehead SS: Genome sequence analysis of $\mathrm{La}$ Crosse virus and in vitro and in vivo phenotypes. Virology Journal 2007, 8:41

51. Armstrong PM, Andreadis TG: A new genetic variant of La Crosse virus (Bunyaviridae) isolated from New England. American Journal of Tropical Medicine and Hygiene 2006, 75:491-496.

52. Grady $\sqcup$, Sanders ML, Campbell WP: The sequence of the M RNA of an isolate of La Crosse virus. Journal of General Virology 1987, 68:3057-3071.

53. Huang C, Thompson WH, Campbell WP: Comparison of the M RNA genome segments of two human isolates of La Crosse virus. Virus Research 1995, 36:177-185.

54. Huang C, Thompson WH, Karabatsos N, Grady L, Campbell WP: Evidence that fatal human infection with La Crosse virus may be associated with a narrow range of genotypes. Virus Research 1997, 48:143-148.

55. Felsenstein J: Evolutionary trees from DNA sequences: a maximum likelihood approach. Journal of Molecular Evolution 1981, 17:368-376.

56. Stamatakis A, Blagojevic F, Nikolopoulos D, Antonopoulos C: Exploring New Search Algorithms and Hardware for Phylogenetics: RAxML Meets the IBM Cell. The Journal of VLSI Signal Processing 2007, 48:271-286.

57. Stamatakis A: RAxML-VI-HPC: maximum likelihood-based phylogenetic analyses with thousands of taxa and mixed models. Bioinformatics 2006:22, bt|446.

58. Librado P, Rozas J: DnaSP v5: A software for comprehensive analysis of DNA polymorphism data. Bioinformatics 2009:1451-1452.

59. Fu Y-X, Li W-H: Statistical tests of neutrality of mutations. Genetics 1993, 133:693-709.

60. Greenacre MJ: Theory and Applications of Correspondence Analysis Academic Press, London; 1984

doi: $10.1186 / 1743-422 X-7-76$

Cite this article as: Reese et al., Identification of super-infected Aedes triseriatus mosquitoes collected as eggs from the field and partial characterization of the infecting La Crosse viruses Virology Journal 2010, 7:76

\section{Submit your next manuscript to BioMed Centra and take full advantage of:}

- Convenient online submission

- Thorough peer review

- No space constraints or color figure charges

- Immediate publication on acceptance

- Inclusion in PubMed, CAS, Scopus and Google Scholar

- Research which is freely available for redistribution

Submit your manuscript at www.biomedcentral.com/submit
C BioMed Central 